\title{
Ants as Indicators in Brazil: A Review with Suggestions to Improve the Use of Ants in Environmental Monitoring Programs
}

\author{
Carla R. Ribas, ${ }^{1}$ Renata B. F. Campos, ${ }^{2}$ Fernando A. Schmidt, ${ }^{3}$ and Ricardo R. C. Solar ${ }^{3}$ \\ ${ }^{1}$ Laboratory of Ant Ecology, Sector of Ecology, Department of Biology, Federal University of Lavras, \\ 37200-000 Lavras, MG, Brazil \\ ${ }^{2}$ Institute of Education of Divinópolis, Educational Foundation of Divinópolis, 35501-170 Divinópolis, MG, Brazil \\ ${ }^{3}$ Post-Graduate Program in Entomology, Department of Entomology, Federal University of Viçosa, \\ 36570-000, Viçosa, MG, Brazil
}

Correspondence should be addressed to Carla R. Ribas, crribas@gmail.com

Received 31 May 2011; Revised 11 August 2011; Accepted 16 August 2011

Academic Editor: Jonathan D. Majer

Copyright (C) 2012 Carla R. Ribas et al. This is an open access article distributed under the Creative Commons Attribution License, which permits unrestricted use, distribution, and reproduction in any medium, provided the original work is properly cited.

We describe the use of ants as indicators in Brazil, based on a critical review of published articles. The analysis of fifty-eight papers, encompassing a range of almost 25 years, indicates an increased number of studies using ants as indicators in the last decade. Among the parameters analyzed in the papers, species composition is the most suitable to evaluate the effect of the disturbance on ant communities. The use of other metrics that consider the specificity and fidelity (e.g., IndVal index) of ant species to a level or state of disturbance is also highly desirable. We discuss several alternative ways of overcoming many of the drawbacks related to the robustness of the results and to reduce the financial, logistic, and time costs involved with the use of ants as indicators in monitoring programs. By doing so, we expect to encourage new research on ants as bioindicators as well as to summarize current knowledge, facilitating further research.

\section{Introduction}

Intensive exploitation of natural resources and the resulting impacts on pristine habitats have led to calls from the scientific community and the general public to measure or monitor the level of these environmental impacts [1-3]. Bioindicators are a useful way to evaluate such impacts, since changes in their population dynamics or community parameters can indicate an environmental state more easily, quickly, and safely and with lower financial and labour inputs than direct measurements [4-6].

McGeoch [7] divided the general use of the term bioindication into three categories according to the three main applications: (i) environmental indicators: used to detect or monitor changes in the environmental state, (ii) ecological indicators: used to demonstrate the impact of an environmental stress on the biota or monitor longer-term stress-induced changes in the biota, and (iii) biodiversity indicators: used to identify the diversity of a taxa in a specified area or to monitor changes in biodiversity.
Therefore, there are several characteristics that an indicator species must have, the most notable being ease of measurement, sensitivity to environmental stress, and predictable responses to environmental stress $[4,8]$. The use of certain species or groups of species as indicators of successful rehabilitation practices or for environmental monitoring has been recommended in recent years (e.g., $[5,6,9]$ ).

Ants have been used as a powerful tool in several ecological studies $[10,11]$. This group has useful characteristics for successful indication and monitoring of environmental impacts, including widespread distribution, high abundance, importance in ecosystem functioning, ease of sampling, and relatively well-known taxonomy and ecology [12].

Thus, ants have been used as indicators of several environmental impacts, such as fire, deforestation and logging, agricultural intensification, mining, and urbanization [13, 14]. The first study suggesting the use of ants as indicators was in the early 1980s [15], and the use of ants as indicators is now widespread in Australia (e.g., [16-19]) and is becoming 
a major focus of myrmecological research worldwide (e.g., [20-25]).

Although ants are a simple, cheap, and powerful indicator of environmental impacts and rehabilitation (e.g., in Australia [17]), in Brazil, a country which harbours enormous diversity and complexity of habitats, the standard use of ants as indicators is still relatively new and should be evaluated in greater detail (see $[26,27])$. According to Philpott et al. [14] and Gardner [6], a critical need is the selection of ant species that are affected by distinct types of disturbance in different regions, in order to guarantee their usefulness as good indicators.

Therefore, as we described above, given the international use of ants as indicators, several studies have investigated the use of ants as indicators in Brazil. In order to describe the background of bioindication with ants in Brazil, we carried out a critical review of several studies concerned directly or indirectly with the use of ants as indicators.

Using the three categories proposed by McGeoch [7], environmental, ecological, or biodiversity indicators, we describe the historical development of ants as indicators and evaluate the implications of these studies. Additionally, we highlight ways of overcoming the major challenges to the widespread use of ants as tools in environmental monitoring programs.

\section{Methods}

We searched for papers regarding ants as indicators, restricting our search to those carried out in Brazil. To encompass a broad time range of papers, we used the following keywords in Portuguese and English, respectively: "formiga," "ant," "indicador," "bioindicador," "indicator," "bioindicator," "Brasil," "Brazil," and the combination of the words cited above in the Scielo and in the ISI Web of Knowledge websites. We also used papers from our personal archives, gathered under several keywords.

In all papers, we accessed the following information: the language, the general idea of the paper (i.e., descriptive, a general survey, a test of correlations or hypotheses), if the paper specifically analyzed ants as indicators; the aims; the ant sampling methodology, the parameters of ant fauna which were analyzed (i.e., diversity, composition, population dynamics), the environmental parameters which were observed, the results which were obtained, and the main conclusion reached in the study.

We define the paper as specifically analyzing ants as indicators if it explicitly declared this intention in the aim or the introduction (Explicit indication papers). However, if this criteria was not clear but the article still analyzed ants as indicators, we defined these as "Implicit indication papers." Papers in which the major aim was not the use of ants as bioindicators, but which presented results that could Potentially enable the use of ants as indicators, were considered as "Potential indication papers." Finally, papers that did not meet any of the above criteria, that is, did not mention in any way the use of ants as indicators, or with results that could not be used to evaluate ants as indicators, were considered as "Indirect bioindication papers."
The disturbances or aims investigated in the papers were split into the categories "Agriculture," "Vegetation type," and "Human land-use," according to the habitats studied, namely: habitats with agricultural activities only, habitats with natural vegetation only, and habitats with both agricultural activities and natural habitats. Similarly, "Succession" studies were those investigating natural succession, and "Restoration" studies were those evaluating different rehabilitation techniques, such as succession following managed restoration efforts.

We used McGeoch [7] as a reference to decide if the ants were used as environmental, ecological, or biodiversity indicators in the reviewed papers (see McGeoch's [7] definition in the introduction section). Moreover, we defined ant species as indicators when there was a species list in the paper showing the occurrence of ants in specific sites or when the author considered the ant species to be an indicator elsewhere in the paper. If the ant species occurred in just one habitat, we considered the species to be an indicator of the specific habitat.

We verified the most frequent responses of ants to disturbance, summarizing responses, and relating the most frequent responses to the most frequently used sampling methodologies to determine if there were any trends. To study this relationship, we considered only methodologies that had been used in at least three papers.

\section{Results}

We analyzed 58 papers, which encompassed a span of almost 25 years (from 1987 to 2010). Among the papers, only one was not classed as an "indication paper" or "Potential indication paper" [83]. The others specifically mentioned the intention to use ants as indicators (either explicitly, using the word "indicator," or implicitly, using ants as a tool or model to indicate the ecological and environmental parameters) (38 papers) or at least have the Potential to do so (17 papers) (Table 1). Two papers $[84,85]$ were not included in the table because the scope of the papers was not to analyse ants as indicators but to suggest new tools to simplify their use as indicators.

From the 58 papers, exactly half (29) were published in English and the other half in Portuguese. Among the "Potential indication papers," 11 were published in English and six in Portuguese, while among the "indication papers" the number of papers written in Portuguese (22) was higher than the papers written in English (18).

Papers directly concerned with the use of ants as bioindicators began almost 10 years after the development of "Potential indication papers", in which the main focus was the response of ant communities to several disturbances (e.g., logging and land use). Only in the last decade has there been a positive trend of papers using ants as model organisms for bioindication in Brazil (Figure 1).

Regarding ant sampling procedures, 34 studies used only a single sampling method: 14 used two, six used three, and four opted for more than three methods. The methodologies used to capture ants were baits, beating, Berlese extraction, 


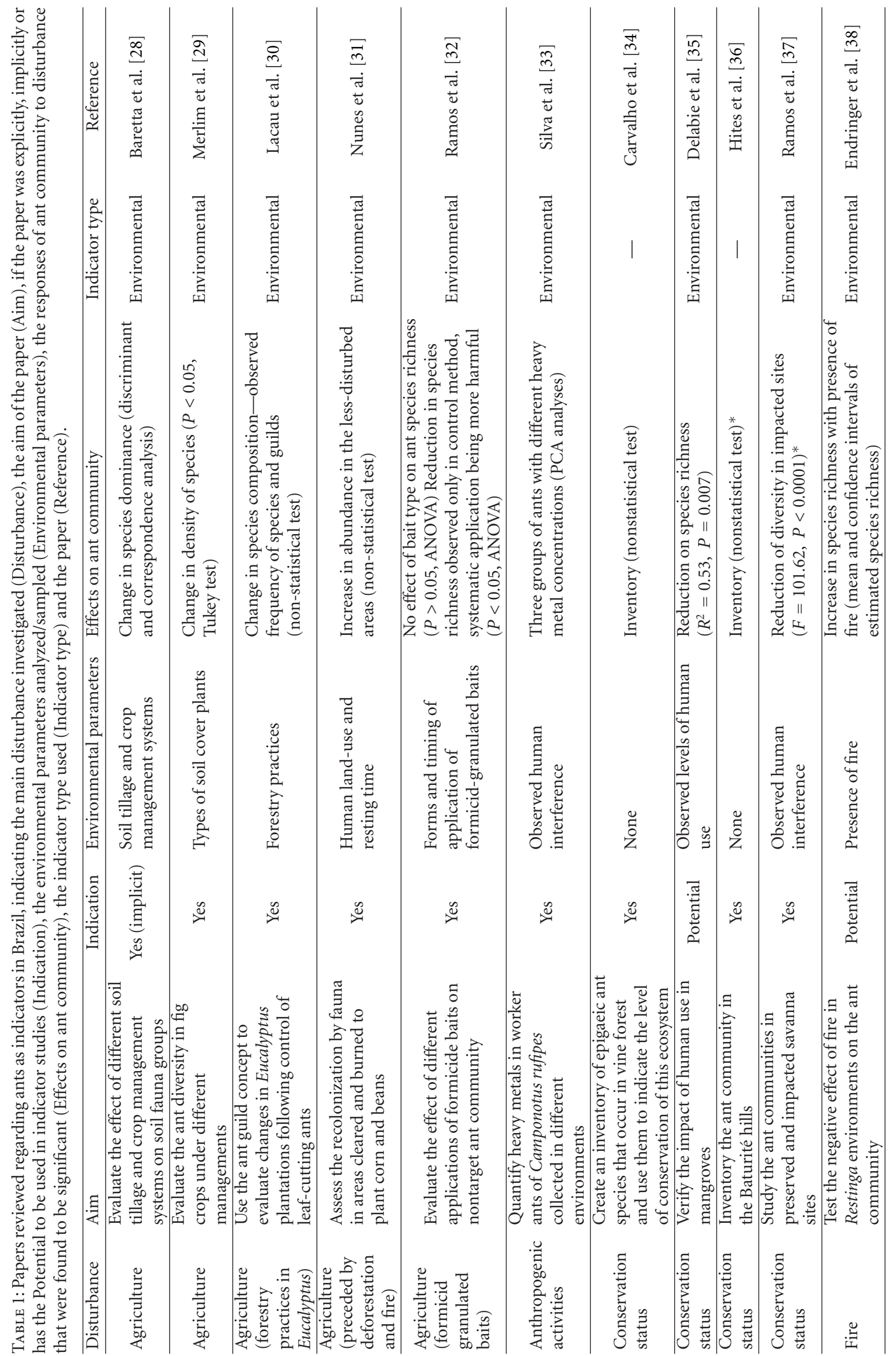




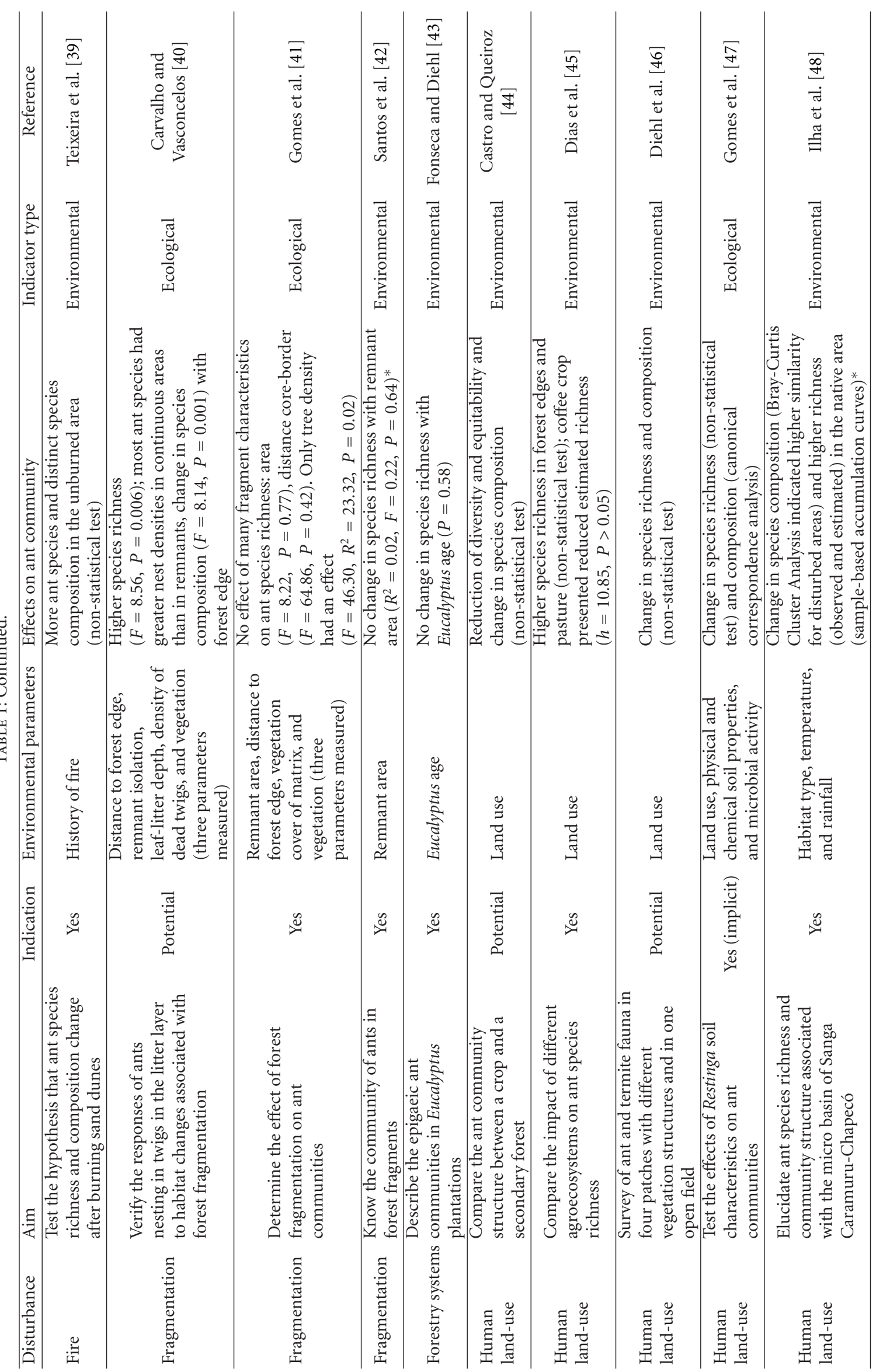




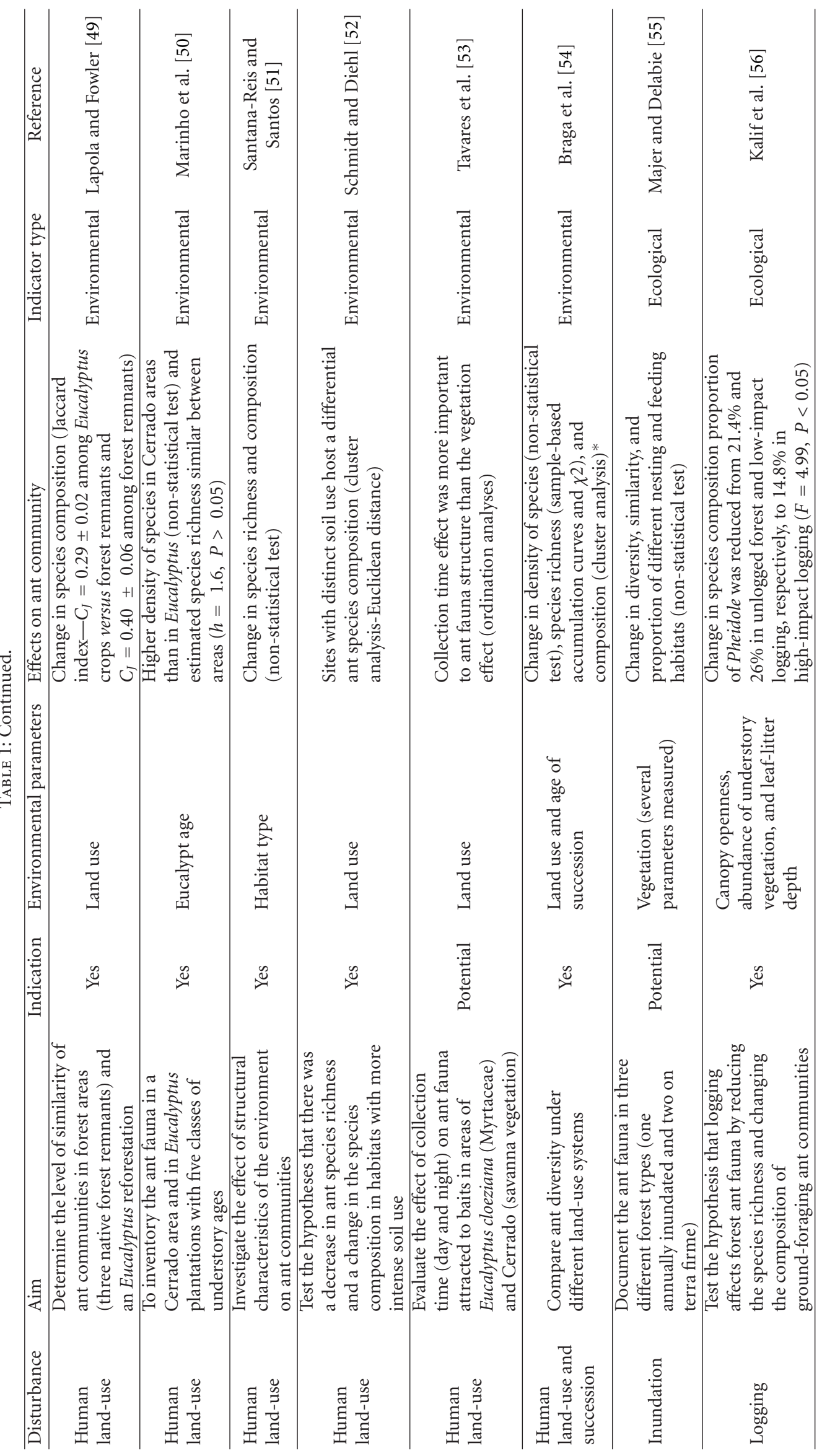




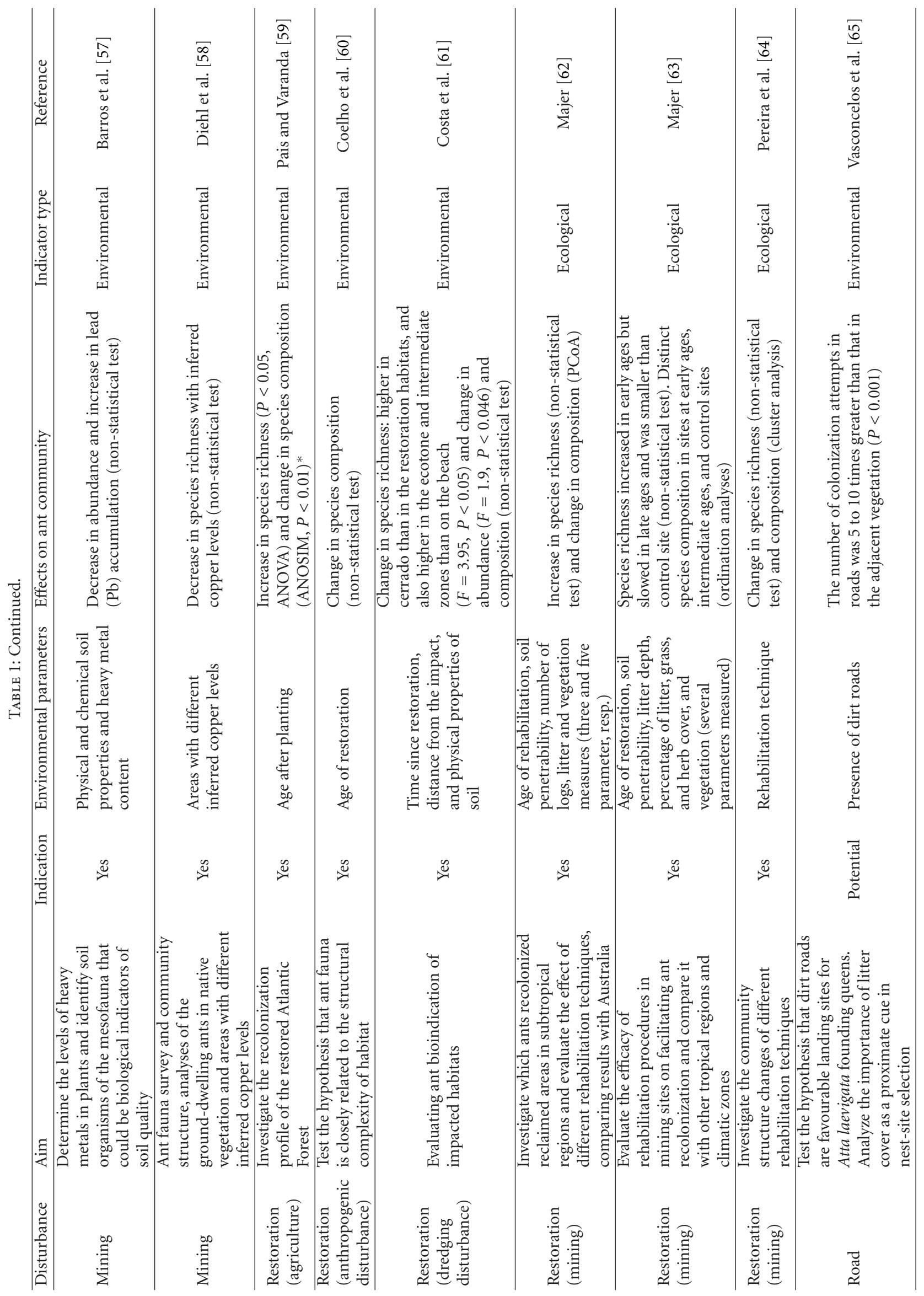




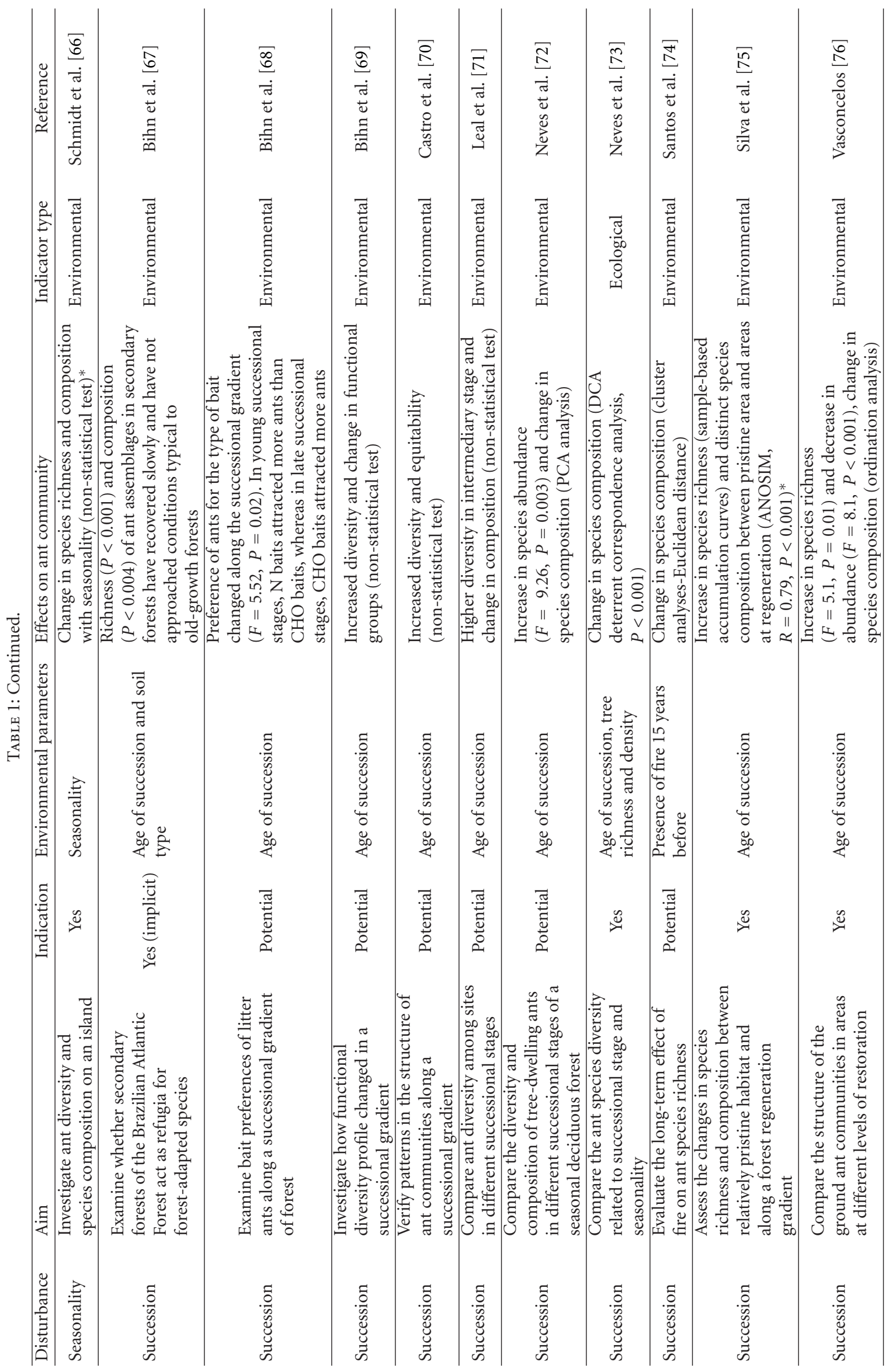




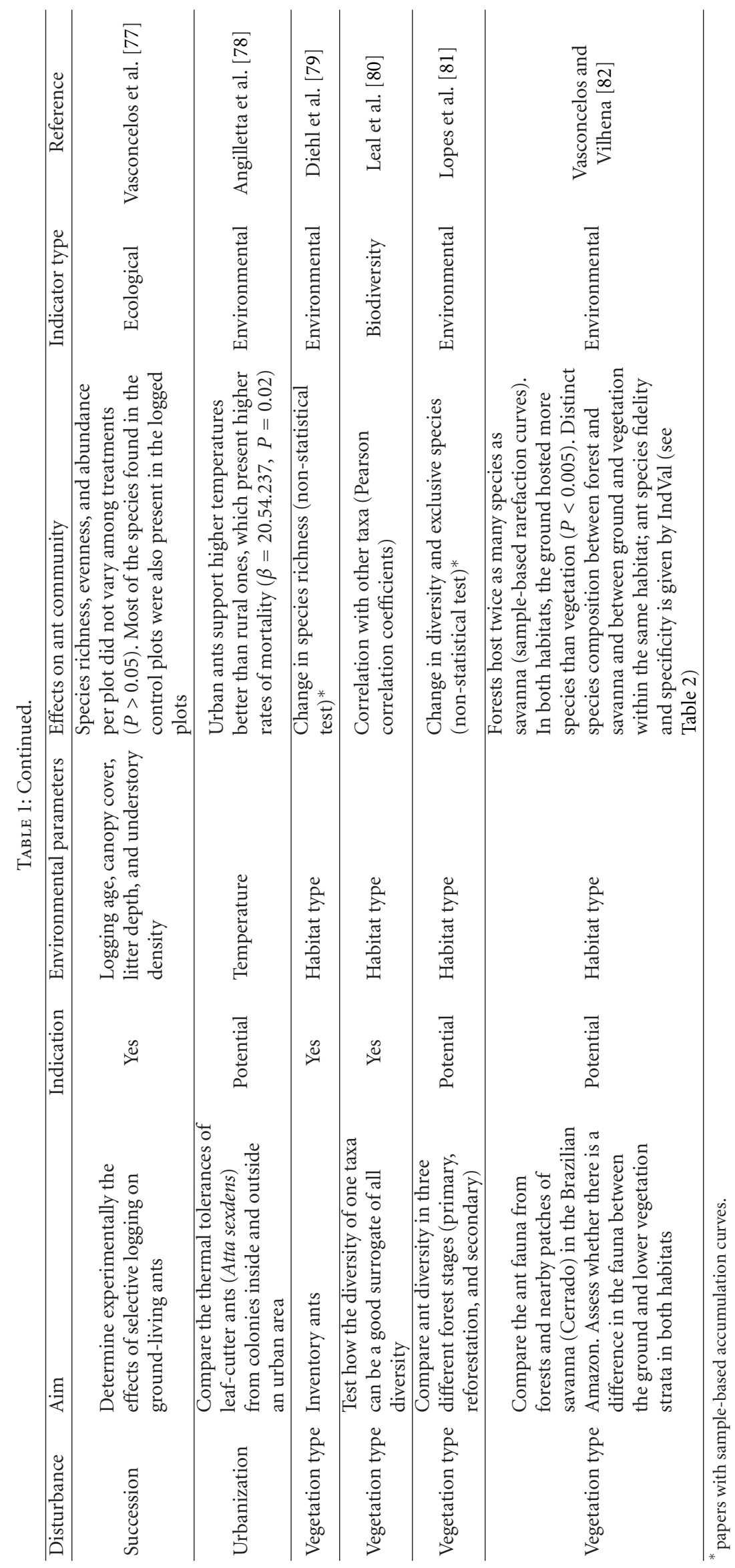




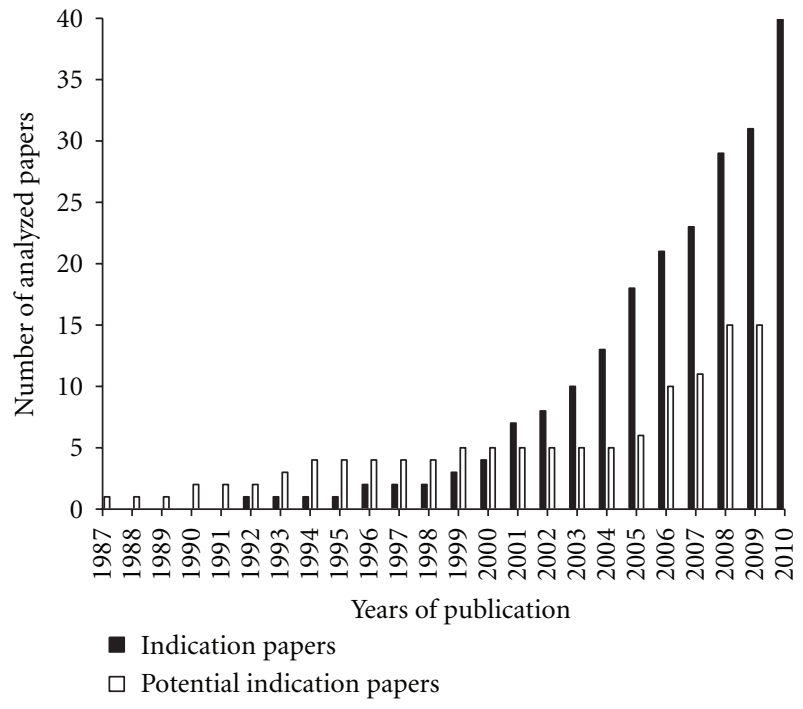

Figure 1: Trend of the number of analyzed papers regarding ants as indicators in Brazil. Indication papers-paper specifies (explicitly or implicitly) the intention of analyzing ants as indicators in the aim or introduction. Potential indication paper-the above criteria was not met, but the paper presents results that could potentially enable the use of ants as indicators.

hand collecting, pitfall traps, sweeping, Tretzel traps and Winkler's extractors. Among these methodologies, the most commonly used were baits (used in 26 studies), followed by hand collecting, pitfall traps and Winkler's extractors (used in 20 studies each), and Berlese extraction (used in five studies).

The majority of studies sampled ants at the soil surface (44), but some studies also considered the soil surface together with other habitats, including litter (10), vegetation (7), combination of the above (6). Some other studies did not sample ants at the soil surface, but only in the litter (11), vegetation (two), or in twigs (one), respectively.

The main impacts studied were succession (12), human land-use (11), restoration (6), and agriculture (5). Just a few papers (13) analyzed other environmental parameters besides disturbance (Table 1).

The parameters of the ant faunas that were most commonly related to the disturbance type were ant species richness or diversity indexes (42) and species composition (35) (Table 1). In these papers, if we considered only those that analyzed ant species diversity and composition rigorously (i.e., with statistical tests), the actual number of papers that analyzed ant species diversity decreased to 28 , and those that analyzed ant species composition dropped to 22 .

Regarding species composition, in 33 papers this parameter was sensitive to disturbance, although if we considered only those papers with statistical analyses, the number decreases to 21. Summarizing the papers that analyze species richness or diversity, the responses found were species richness or diversity increased with disturbance (1), decreased with disturbance (18), changed with disturbance (when there is any clear trend in the response of ants to disturbance) (11), and not affected by disturbance (12). If we considered only papers that tested ant species richness or diversity statistically, the numbers changed to increase with disturbance (1), decrease with disturbance (11), change with disturbance (5), and not affected by disturbance (11).

By connecting the main responses found in the papers (ant species richness, diversity, or ant species composition) to the main methodologies used to sample ants, we can verify some trends (Figure 2). First, species composition was sensitive to disturbance in the majority of papers in which this parameter was tested, irrespective of the sampling methodology, namely, baits plus hand collecting, multiple sampling methods, or pitfall traps. Second, most papers that analyzed species richness or diversity showed that these metrics were also responsive to disturbance, although the sole use of baits or the Winkler did not show any trend, while only using pitfall traps revealed a positive response of ant species richness or diversity to disturbance. Nevertheless, when we considered only those papers with statistical tests (Figure 3) or without statistical tests (Figure 4), the trend for species composition remained the same, but for species richness the use of multiple methods to sample ants showed a higher number of responses to disturbance.

The ants were used as environmental indicators in the majority of studies (42 out of 55) but were also used as ecological indicators (10 papers) and as biodiversity indicators in only one paper. In 20 papers there was a species list, and; therefore, we could determine some of the ant species that served as indicators of certain habitats. The parameters used in the papers to define a species as an indicator were frequency of ant occurrence (11 papers), presence or absence of ant species (8 papers), and the indicator value (IndVal) (1 paper). Irrespective of the parameter used by the authors, 187 ant species were defined as indicators and linked to specific habitats (Table 2). The genera with higher numbers of indicator species were Camponotus (18), Pseudomyrmex (12), Pachycondyla (11), Ectatomma (9), Gnamptogenys (9), Acromyrmex (8), and Cephalotes (8). The sites with the most indicator species were forest (39 species), Eucalyptus (37), savanna (34), control or undisturbed sites (nonburnt) (29), primary forest (25), early succession sites (19), disturbed sites (15), secondary forest (14), intermediate succession sites (13), burnt sites, low human land-use-impacted sites and pasture (9), late succession (8), and strong human land-useimpacted sites (5).

\section{Discussion}

It has been possible to determine the history of research carried out in Brazil by searching for the use of ants as indicators over the last 25 years (Figure 1). From 1987 to 1991, there were only "Potential indication papers." In 1992 the first "Indication papers" were published, which increased in the following years and exceeded the "Potential indication papers" in 2001 .

Regarding the idiom of the papers, it is interesting to observe that half of the papers are still published in Portuguese. In spite of the growing internationalization of Brazilian 


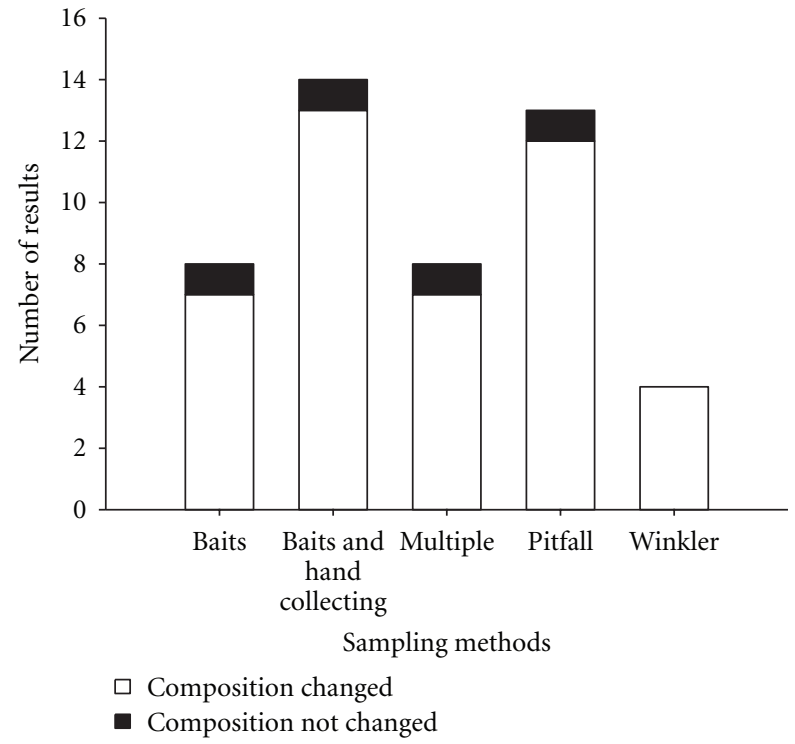

(a)

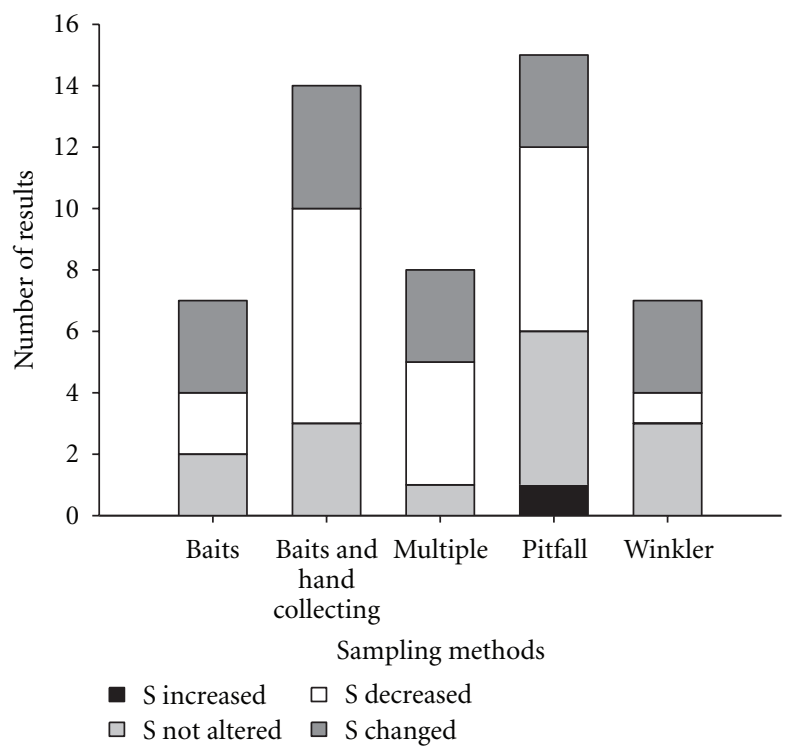

(b)

Figure 2: Papers that analyzed (a) ant species composition and/or (b) ant species richness/diversity with and without statistical tests and their responses to habitat disturbance through the use of different ant sampling methodologies. Composition changed—species composition altered by disturbance. Composition not changed—-species composition not altered by disturbance. S increased—species richness or diversity increased with disturbance. S not altered-species richness or diversity not affected by disturbance. S decreased-species richness or diversity decreased with disturbance. $S$ changed—-species richness or diversity changed with disturbance when there is any clear trend in the response of ants to disturbance.

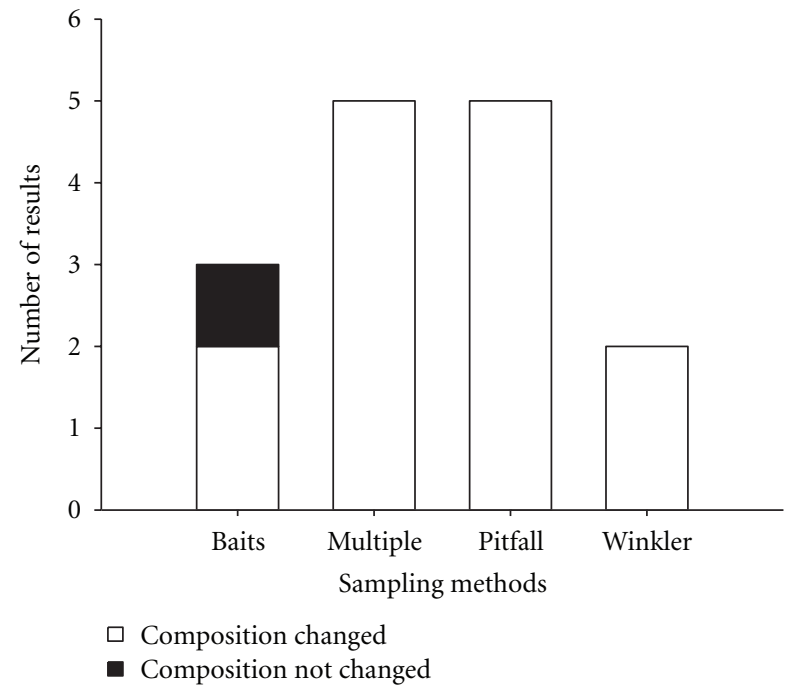

(a)

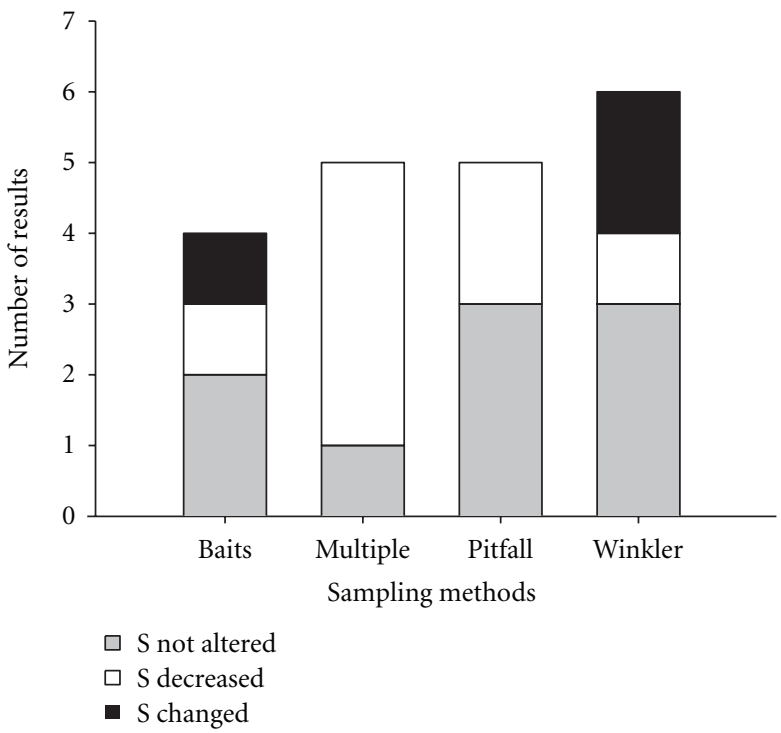

(b)

FIGURE 3: Papers that analyzed (a) ant species composition and/or (b) ant species richness/diversity with statistical tests and their responses to habitat disturbance through the use of different ant sampling methodologies. Composition changed-species composition altered by disturbance. Composition not changed—species composition not altered by disturbance. S increased—species richness or diversity increased with disturbance. S not altered—species richness or diversity not affected by disturbance. S decreased—species richness or diversity decreased with disturbance. S changed-species richness or diversity changed with disturbance when there is any clear trend in the response of ants to disturbance. 


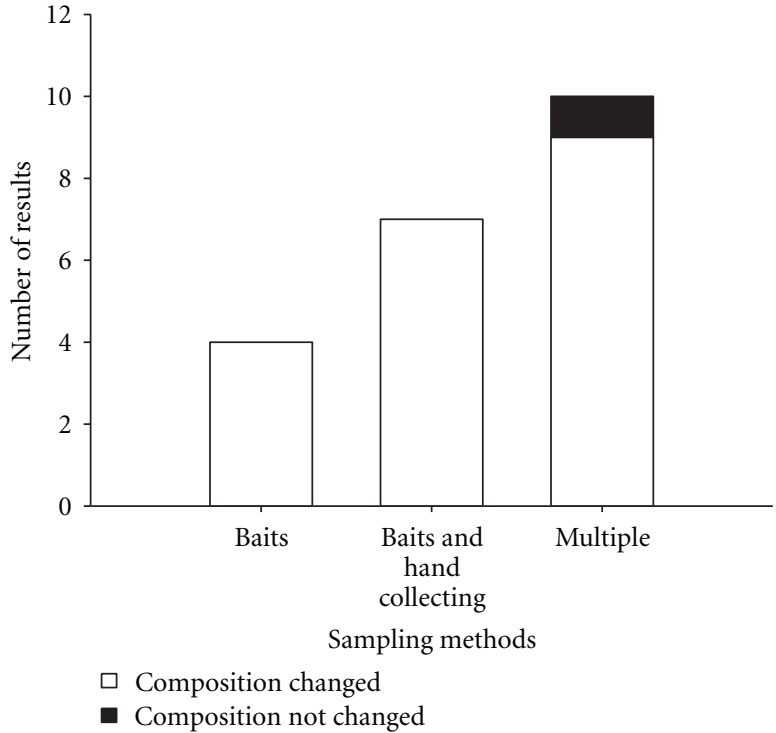

(a)

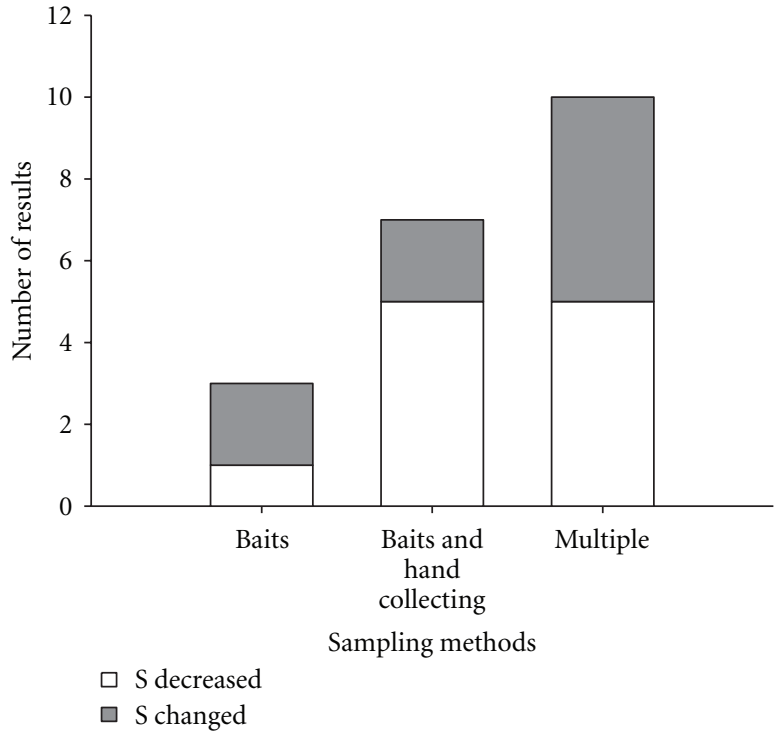

(b)

Figure 4: Papers that analyzed (a) ant species composition and/or (b) ant species richness/diversity without statistical tests and their responses to habitat disturbance through the use of different ant sampling methodologies. Composition changed—species composition altered by disturbance. Composition not changed—species composition not altered by disturbance. S increased-species richness or diversity increased with disturbance. S not altered — species richness or diversity not affected by disturbance. S decreased-species richness or diversity decreased with disturbance. $S$ changed - species richness or diversity changed with disturbance when there is any clear trend in the response of ants to disturbance.

research [86, 87], many Brazilian studies that use ants as bioindicators cannot have an international impact since they are in Portuguese. We determined at least two main reasons for this. The first is the "publish or perish" policy in Brazilian (and worldwide) science, which demands the publication of as many papers as possible in the shortest feasible time span, in which case publishing in Portuguese can be a way to speed up publication time. The second explanation may be that, due to problems with the style of writing of the papers, many international journals reject Brazilian papers. Despite these two issues, in this historical scenario, there is an improving and maturing of bioindication studies using ants, which is shown by the explicit use of the term "indication" in these papers. Furthermore, the increasing knowledge exchange with researchers from other countries reinforces the maturation of this area of research. Examples include Brazilian scientists that complete their Ph.D. studies abroad the possibility for doctorate students to undertake international exchange programs, and the internationalization of the Brazilian Symposium of Myrmecology.

However, it is important to clarify that although some authors explicitly used the term indicator in the introduction or in the aim of their papers (our criteria defined these papers as "Indication papers"), the authors did not always in reality use ants as indicators, either because they did not sample properly (i.e., sampling in just one habitat, without different levels of the disturbance/restoration and control sites) or because they did not analyze their results rigorously (i.e., did not include a satisfactory statistical analysis). Conversely, some authors did not use the term indicator in their papers, but they did test the Potential use of ants as indicators, and were cautious in the above points.

The majority of articles that used ants as environmental indicators (sensu [7]) may be due to the fact that this is the simplest way to detect a change in the environmental state of the habitat but not necessarily the best one. The use of ecological indicators has the advantage of encompassing a broad response as they demonstrate the disturbance effect on the biota, not only for ants [6].

Moreover, the sampling of different environmental parameters and their correlation with the biota is essential, because their inclusion increases the predictive power of the study. If we recognize the environmental parameters that are most sensitive to disturbance and their effect on the biota, we may be able to more accurately monitor the effects of disturbance. Consequently, we may be able to choose the restoration effort according to the most appropriate or effective environmental parameters in order to promote the recovery of the biota $[6,7]$.

Regarding the number of ant sampling techniques used, although the majority of the papers used only one method, several studies (e.g., [52, 77, 88]) have highlighted the fact that ant communities show a pronounced vertical stratification, and ant faunas specific to each microhabitat may present specific ecological traits and distinct sensitivity to the same environmental impact [67, 89-91]; therefore, more than one sampling method must be considered [13]. On the other hand, the use of several sampling methods increases the financial costs and the time needed to collect, sort, and process the data [13]. Thus, since environmental monitoring 
programs usually have short-term goals, it is desirable to balance the benefits and costs of using several types of sampling methods compared to using only one sampling method which could achieve similar reliable results (Figures 2(a) and 2(b)), compare multiple sampling and pitfall outcomes) about the patterns and aims under investigation.

The most used sampling method in the studies was attractive baits, which are more suitable for behavioural questions [92] and are useful for verifying the presence and population trends of invasive and keystone ant species [13]. However, this sampling method results in biased information about ant diversity (e.g., species richness and composition) because many ants have selective diets, and some ants can dominate the baits to the exclusion of a broad range of other ant species [92]. This notion concerning the use of baits in bioindication papers is confirmed in Figures 3(a) and 3(b), which shows that the sole use of baits revealed apparently unchanging species composition and no trend in species richness. Thus, Underwood and Fisher [13] recommend the use of pitfall traps and litter sampling (The Winkler and/or Berlese extractors) as effective ant sampling methods for monitoring goals related to the effect of habitat disturbance and transformation on ant diversity, which is corroborated in Figures 3(a), 3(b), 4(a), and 4(b).

Species richness and diversity and species composition are the parameters of ant communities most commonly analyzed in the papers. However, species richness and diversity should be used as an evaluative method with caution, since several studies have shown that these parameters were not affected by disturbance (Table 1), and only a narrow number of papers showed a trend in the response of ant species richness to disturbance (see Figures 3 and 4). This coarse relationship of species richness to disturbance is probably because ants are generalists, so the loss of some sensitive species to disturbance is compensated by the invasion of other opportunist species or more generalists. Moreover, in dynamic sites under frequent habitat transformation and disturbance, there is no change in species richness among sites at different restoration times, because perturbation events "reset" the ant community to the same stage [93].

In this way, as Hoffmann [94] has highlighted, the disturbance induced changes in species composition, but not necessarily in species richness. Moreover, the recovery of species composition takes longer than species richness [95] and has a strong relation to the vegetation structure $[19,64$, 96-99], which changes with disturbance events. Thus, species composition should be a better parameter to evaluate the effect of disturbance on ant communities, even in areas with frequent perturbations, as described by Gollan et al. [93].

Using the same argument, the quantification of the relationship between each ant species and different disturbances (or level of disturbance) or habitats should be very useful, as it is important to decrease the time spent in indication studies. The general public and stakeholders need to know rapidly if the habitat is impacted or recovering, so recognizing which species can be associated positively or negatively with disturbance or restoration is a very desirable tool.

Several of the papers we analyzed described species occurring exclusively or more frequently in specific habitats
(Table 2), but we are concerned with the lack of rigour with which this has been carried out in most studies (exception in [82]), as there is no control about the specificity and fidelity of these ant species and few statistical analyses to validate the results. This lack of rigour may explain why there are some ant species with contradictory patterns of occurrence, such as species being present in disturbed versus undisturbed sites, such as Acromyrmex balzani, Camponotus trapezoideus, Dorymyrmex pyramicus, Ectatomma tuberculatum, Odontomachus haematodus, and Pseudomyrmex tenuis (see Table 2). Moreover, these ant species might also be generalists, and the choice of better criteria should enable us to distinguish between inappropriate sampling design and truly generalist ant species. The use of the IndVal index [8], mentioned below, is one option to overcome this drawback.

The Indicator Value (IndVal) suggested by Dufrêne and Legendre [8] combines a measure of the habitat specificity of a species to a level of disturbance, or to a disturbance state, with its fidelity within that state. The random reallocation procedure of samples within sample groups can be used to test the significance of the IndVal measure for each species. The use of this method has increased (e.g., [100-105]) and has a number of advantages over other methods [6].

Some species seem to have more consistent responses to disturbance or specificity to some habitats, but this consistency is very difficult to assert due to the lack of rigour with which the ants were related to disturbance or habitats (presence or frequency of occurrence) and the lack of standardization regarding the level of disturbance in the papers. The habitats sampled in one paper may be defined as undisturbed, which may be different from the habitats studied in another paper that are defined as more degraded (or less) and should also be defined as an undisturbed habitat. In our paper (including Table 2), we used the definition of disturbed or undisturbed given by the original authors.

Thus, following the disturbance definition used by the authors, some species are present in disturbed habitats in more than one paper, and, therefore, could be indicators of disturbed habitats, such as Atta sexdens rubropilosa, Camponotus crassus, Camponotus melanoticus, Camponotus novogranadensis, Odontomachus meinerti, Pachycondyla villosa, Pseudomyrmex termitarius, and Solenopsis saevissima. In the same way, some species could be indicators of undisturbed habitats, such as Labidus coecus, Pachycondyla arhuaca, Pachycondyla stigma, and Sericomymex bondari. There are also some species that are indicators of specific habitats, such as indicators of forests (Discothyrea sexarticulata, Ectatomma lugens, Labidus coecus, and Typhlomyrmex major) and indicators of savannas (Camponotus latangulus, Pheidole fimbriata, and Strumigenys perparva).

One of the major mistakes related to the use of a taxon as an indicator is the personal motivation of the researchers. There are two ways of avoiding this mistake; several taxa should be rigorously tested a priori to select the best one [4] or studied a posteriori to validate the response of the indicator [7]. Very few studies have compared how different taxa, including ants, perform under different disturbances (see [89, 101, 106-109]). 
$[\mathrm{t} !]$

TABle 2: Species of ants defined as indicators, indicating the parameter used by the authors (Parameter) when linking each ant species to each habitat type (Habitat) and the paper (Reference).

\begin{tabular}{|c|c|c|c|}
\hline Ant species & Parameter & Habitat & Reference \\
\hline Acanthognathus brevicornis & Frequency of occurrence & Secondary forest and area at early succession & Silva et al. [75] \\
\hline Acanthognathus ocellatus & Frequency of occurrence & Primary forest & Silva et al. [75] \\
\hline Acanthognathus rudis & Frequency of occurrence & Primary forest & Silva et al. [75] \\
\hline Acanthoponera mucronata & Frequency of occurrence & Native forest remnant & Ilha et al. [48] \\
\hline \multirow[t]{3}{*}{ Acromyrmex balzani } & Presence/absence & Eucalyptus forestry & Marinho et al. [50] \\
\hline & Presence/absence & Low human land-use-impacted sites & Delabie et al. [35] \\
\hline & Presence/absence & Undisturbed sites—control site & Diehl et al. [58] \\
\hline \multirow[t]{2}{*}{ Acromyrmex coronatus } & Frequency of occurrence & Forest fragments & Lapola and Fowler [49] \\
\hline & Frequency of occurrence & Preserved savanna & Ramos et al. [37] \\
\hline Acromyrmex lobicornis & Presence/absence & Undisturbed sites—control site & Diehl et al. [58] \\
\hline Acromyrmex lundi & Frequency of occurrence & Secondary forest & Schmidt and Diehl [52] \\
\hline Acromyrmex niger & Presence/absence & Eucalyptus forestry & Marinho et al. [50] \\
\hline Acromyrmex rugosus & Frequency of occurrence & Turnera ulmifolia field & $\begin{array}{l}\text { Santana-Reis and } \\
\text { Santos }[51]\end{array}$ \\
\hline Acromyrmex striatus & Presence/absence & Undisturbed sites — control site & Diehl et al. [58] \\
\hline Acromyrmex subterraneus & Frequency of occurrence & Forest fragments & Lapola and Fowler [49] \\
\hline Acromyrmex subterraneus brunneus & Presence/absence & Eucalyptus forestry & Marinho et al. [50] \\
\hline Acromyrmex subterraneus subterraneus & $s \quad$ Presence/absence & Eucalyptus forestry & Marinho et al. [50] \\
\hline Acropyga decedens & Frequency of occurrence & Pasture & Dias et al. [45] \\
\hline \multirow[t]{3}{*}{ Amblyopone armigera } & Frequency of occurrence & Preserved savanna & Ramos et al. [37] \\
\hline & Presence/absence & Savanna—cerrado sensu stricto & Marinho et al. [50] \\
\hline & Frequency of occurrence & Secondary forest and area at early succession & Silva et al. [75] \\
\hline Amblyopone elongata & Frequency of occurrence & Primary forest & Silva et al. [75] \\
\hline Anochetus diegensis & Frequency of occurrence & Preserved savanna & Ramos et al. [37] \\
\hline Anochetus mayri & Frequency of occurrence & Control site (nonburnt) & Teixeira et al. [39] \\
\hline Anochetus neglectus & Frequency of occurrence & Pasture & Dias et al. [45] \\
\hline Anochetus targionii & Frequency of occurrence & Pasture & Dias et al. [45] \\
\hline Apterostigma acre & Frequency of occurrence & Forest fragment & Dias et al. [45] \\
\hline Apterostigma bolivianum & Frequency of occurrence & Forest fragment & Dias et al. [45] \\
\hline Atta robusta & Frequency of occurrence & Control site (nonburnt) & Teixeira et al. [39] \\
\hline \multirow{3}{*}{ Atta sexdens rubropilosa } & Presence/absence & Area at early succession & Coelho et al. [60] \\
\hline & Frequency of occurrence & Disturbed savanna & Ramos et al. [37] \\
\hline & Presence/absence & Eucalyptus forestry & Marinho et al. [50] \\
\hline Azteca alfari & Presence/absence & Area at late succession stage-dry season & Neves et al. [73] \\
\hline Azteca muelleri & Frequency of occurrence & Control site (nonburnt) & Teixeira et al. [39] \\
\hline Basiceros disciger & Frequency of occurrence & Forest fragments & Lapola and Fowler [49] \\
\hline Blepharidatta brasiliensis & Frequency of occurrence & Area at late succession stage & Vasconcelos [76] \\
\hline Brachymyrmex coactus & Frequency of occurrence & Secondary forest and area at early succession & Silva et al. [75] \\
\hline Camponotus arboreus & Frequency of occurrence & Control site (nonburnt) & Teixeira et al. [39] \\
\hline Camponotus atriceps & Presence/absence & Reforestated area at intermediate succession stage & Coelho et al. [60] \\
\hline Camponotus bidens & Presence/absence & Low human land-use-impacted sites & Delabie et al. [67 \\
\hline Camponotus burtoni & Presence/absence & Eucalyptus forestry & Marinho et al. [50] \\
\hline Camponotus claviscapus & Presence/absence & Undisturbed sites & Delabie et al. [35] \\
\hline \multirow[t]{4}{*}{ Camponotus crassus } & Presence/absence & Burned restinga & Endringer et al. [38] \\
\hline & Frequency of occurrence & Burnt site & Teixeira et al. [39] \\
\hline & Frequency of occurrence & Disturbed sites & Diehl et al. [58] \\
\hline & Frequency of occurrence & Secondary forest and forest edge & Leal et al. [71] \\
\hline
\end{tabular}


Table 2: Continued.

\begin{tabular}{|c|c|c|c|}
\hline Ant species & Parameter & Habitat & Reference \\
\hline & IndVal & Savanna-vegetation and ground stratum & $\begin{array}{l}\text { Vasconcelos and } \\
\text { Vilhena [82] }\end{array}$ \\
\hline Camponotus fastigatus & Frequency of occurrence & Preserved savanna & Ramos et al. [37] \\
\hline \multirow[t]{2}{*}{ Camponotus latangulus } & Frequency of occurrence & Preserved savanna & Ramos et al. [37] \\
\hline & Presence/absence & Savanna—cerrado sensu stricto & Marinho et al. [50] \\
\hline Camponotus leydigi & Frequency of occurrence & Area at early succession & Vasconcelos [76] \\
\hline \multirow[t]{3}{*}{ Camponotus melanoticus } & Presence/absence & Eucalyptus forestry & Marinho et al. [50] \\
\hline & Frequency of occurrence & Pasture & Dias et al. [45] \\
\hline & Presence/absence & Area at early succession & Coelho et al. [60] \\
\hline \multirow[t]{4}{*}{ Camponotus novogranadensis } & Frequency of occurrence & Area at early succession & Vasconcelos [76] \\
\hline & Presence/absence & Eucalyptus forestry & Marinho et al. [50] \\
\hline & IndVal & Forest—vegetation and ground stratum & $\begin{array}{c}\text { Vasconcelos and } \\
\text { Vilhena [82] }\end{array}$ \\
\hline & Frequency of occurrence & Disturbed savanna & Ramos et al. [37] \\
\hline Camponotus punctatus minutior & Frequency of occurrence & Preserved savanna & Ramos et al. [37] \\
\hline Camponotus renggeri & Presence/absence & Eucalyptus forestry & Marinho et al. [50] \\
\hline \multirow[t]{3}{*}{ Camponotus rufipes } & Frequency of occurrence & Disturbed savanna & Ramos et al. [37] \\
\hline & Presence/absence & Eucalyptus forestry & Marinho et al. [50] \\
\hline & Frequency of occurrence & Forest fragments & Lapola and Fowler [49] \\
\hline Camponotus sericeiventris & Frequency of occurrence & Native forest remnant & Ilha et al. [48] \\
\hline \multirow{3}{*}{ Camponotus trapezoideus } & Frequency of occurrence & Burnt site & Teixeira et al. [39] \\
\hline & Frequency of occurrence & Forest fragment & Dias et al. [45] \\
\hline & Frequency of occurrence & Preserved savanna & Ramos et al. [37] \\
\hline Camponotus vitatus & Presence/absence & Low human land-use-impacted sites & Delabie et al. [35] \\
\hline Camponotus westermanni & Presence/absence & Strong human land-used-impacted sites & Delabie et al. [35] \\
\hline Cardiocondyla obscurior & Presence/absence & Area at intermediate succession & Coelho et al. [60] \\
\hline Carebara urichi & Frequency of occurrence & Preserved savanna & Ramos et al. [37] \\
\hline \multirow[t]{2}{*}{ Cephalotes atratus } & Frequency of occurrence & Control site (nonburnt) & Teixeira et al. [39] \\
\hline & IndVal & Forest—vegetation stratum & $\begin{array}{c}\text { Vasconcelos and } \\
\text { Vilhena [82] }\end{array}$ \\
\hline Cephalotes grandinosus & Presence/absence & Forest & Lopes et al. [81] \\
\hline \multirow{2}{*}{ Cephalotes minutus } & Presence/absence & Area at early succession-dry season & Neves et al. [73] \\
\hline & Presence/absence & Low human land-use-impacted sites & Delabie et al. [35] \\
\hline Cephalotes pallidicephalus & Presence/absence & Low human land-use-impacted sites & Delabie et al. [35] \\
\hline Cephalotes pavonii & Frequency of occurrence & Burnt site & Teixeira et al. [39] \\
\hline Cephalotes pellans & Presence/absence & Area at intermediate succession—wet season & Neves et al. [73] \\
\hline Cephalotes pusillus & IndVal & Savanna-vegetation and ground stratum & $\begin{array}{l}\text { Vasconcelos and } \\
\text { Vilhena [82] }\end{array}$ \\
\hline Cephalotes simillimus & IndVal & Savanna-vegetation stratum & $\begin{array}{l}\text { Vasconcelos and } \\
\text { Vilhena [82] }\end{array}$ \\
\hline Crematogaster brasiliensis & IndVal & Forest—vegetation and ground stratum & $\begin{array}{c}\text { Vasconcelos and } \\
\text { Vilhena [82] }\end{array}$ \\
\hline \multirow[t]{2}{*}{ Crematogaster erecta } & Presence/absence & Area at intermediate succession & Coelho et al. [60] \\
\hline & IndVal & Savanna-vegetation and ground stratum & $\begin{array}{l}\text { Vasconcelos and } \\
\text { Vilhena [82] }\end{array}$ \\
\hline Crematogaster limata & IndVal & Forest—vegetation and ground stratum & $\begin{array}{c}\text { Vasconcelos and } \\
\text { Vilhena [82] }\end{array}$ \\
\hline Crematogaster minutissima & IndVal & Forest—ground stratum & $\begin{array}{l}\text { Vasconcelos and } \\
\text { Vilhena [82] }\end{array}$ \\
\hline Crematogaster nigropilosa & Frequency of occurrence & Native forest remnant & Ilha et al. [48] \\
\hline
\end{tabular}


Table 2: Continued.

\begin{tabular}{|c|c|c|c|}
\hline Ant species & Parameter & Habitat & Reference \\
\hline Crematogaster quadriformis & IndVal & Savanna—ground stratum & $\begin{array}{l}\text { Vasconcelos and } \\
\text { Vilhena [82] }\end{array}$ \\
\hline Cyphomyrmex laevigatus & Frequency of occurrence & Forest fragments & Lapola and Fowler [49] \\
\hline Cyphomyrmex major & Frequency of occurrence & Forest fragments & Lapola and Fowler [49] \\
\hline Cyphomyrmex olitor & Frequency of occurrence & Primary forest & Silva et al. [75] \\
\hline \multirow[t]{3}{*}{ Cyphomyrmex peltatus } & Frequency of occurrence & Disturbed savanna & Ramos et al. [37] \\
\hline & Presence/absence & Eucalyptus forestry & Marinho et al. [50] \\
\hline & Frequency of occurrence & Forest fragments & Dias et al. [45] \\
\hline Cyphomyrmex plaumanni & Frequency of occurrence & Primary forest & Silva et al. [75] \\
\hline \multirow[t]{2}{*}{ Cyphomyrmex salvini } & Frequency of occurrence & Area at early succession & Vasconcelos [76] \\
\hline & Frequency of occurrence & Control site (nonburnt) & Teixeira et al. [39] \\
\hline Cyphomyrmex transversus & Frequency of occurrence & Preserved savanna & Ramos et al. [37] \\
\hline \multirow[t]{2}{*}{ Discothyrea sexarticulata } & Frequency of occurrence & Forest fragment & Dias et al. [45] \\
\hline & Frequency of occurrence & Primary forest & Silva et al. [75] \\
\hline Dolichoderus attelaboides & IndVal & Forest—vegetation stratum & $\begin{array}{l}\text { Vasconcelos and } \\
\text { Vilhena [82] }\end{array}$ \\
\hline Dolichoderus bispinosus & IndVal & Forest—vegetation stratum & $\begin{array}{l}\text { Vasconcelos and } \\
\text { Vilhena [82] }\end{array}$ \\
\hline Dolichoderus schulzi & Presence/absence & Undisturbed sites & Delabie et al. [35] \\
\hline Dolichoderus voraginosus & Presence/absence & Area at early succession—dry season & Neves et al. [73] \\
\hline Dorymyrmex guianensis & IndVal & Savanna-ground stratum & $\begin{array}{c}\text { Vasconcelos and } \\
\text { Vilhena [82] }\end{array}$ \\
\hline \multirow[t]{2}{*}{ Dorymyrmex pyramicus } & Frequency of occurrence & Burnt site & Teixeira et al. [39] \\
\hline & Presence/absence & Undisturbed sites & Delabie et al. [35] \\
\hline Dorymyrmex thoracicus & IndVal & Savanna—ground stratum & $\begin{array}{c}\text { Vasconcelos and } \\
\text { Vilhena [82] }\end{array}$ \\
\hline Eciton quadriglume & Frequency of occurrence & Forest fragments & Lapola and Fowler [49] \\
\hline \multirow[t]{3}{*}{ Ectatomma brunneum } & Presence/absence & Eucalyptus forestry & Marinho et al. [50] \\
\hline & Frequency of occurrence & Area at early succession & Braga et al. [54] \\
\hline & Presence/absence & Low human land-use-impacted sites & Delabie et al. [35] \\
\hline Ectatomma edentatum & Frequency of occurrence & Preserved savanna & Ramos et al. [37] \\
\hline \multirow[t]{2}{*}{ Ectatomma lugens } & Frequency of occurrence & Area at late succession stage & Vasconcelos [76] \\
\hline & IndVal & Forest—ground stratum & $\begin{array}{c}\text { Vasconcelos and } \\
\text { Vilhena [82] }\end{array}$ \\
\hline Ectatomma muticum & Frequency of occurrence & Control site (nonburnt) & Teixeira et al. [39] \\
\hline Ectatomma opaciventre & IndVal & Savanna-ground stratum & $\begin{array}{c}\text { Vasconcelos and } \\
\text { Vilhena [82] }\end{array}$ \\
\hline \multirow[t]{3}{*}{ Ectatomma permagnum } & Frequency of occurrence & Control site (nonburnt) & Teixeira et al. [39] \\
\hline & Frequency of occurrence & Eucalyptus forestry & Braga et al. [54] \\
\hline & Presence/absence & Eucalyptus forestry & Marinho et al. [50] \\
\hline \multirow[t]{2}{*}{ Ectatomma planidens } & Frequency of occurrence & Disturbed savanna & Ramos et al. [37] \\
\hline & Presence/absence & Eucalyptus forestry & Marinho et al. [50] \\
\hline Ectatomma quadridens & Frequency of occurrence & Area at early succession & Vasconcelos [76] \\
\hline \multirow[t]{5}{*}{ Ectatomma tuberculatum } & Frequency of occurrence & Area at early succession & Silva et al. [75] \\
\hline & Presence/absence & Burned restinga & Endringer et al. [38] \\
\hline & Presence/absence & Eucalyptus forestry & Marinho et al. [50] \\
\hline & Frequency of occurrence & Area at late succession stage & Braga et al. [54] \\
\hline & Frequency of occurrence & Secondary forest and forest edge & Leal et al. [71] \\
\hline Forelius maranhoensis & IndVal & Savanna-ground stratum & $\begin{array}{l}\text { Vasconcelos and } \\
\text { Vilhena }[82]\end{array}$ \\
\hline Gnamptogenys acuminata & Frequency of occurrence & Forest fragments & Lapola and Fowler [49] \\
\hline
\end{tabular}


Table 2: Continued.

\begin{tabular}{|c|c|c|c|}
\hline Ant species & Parameter & Habitat & Reference \\
\hline Gnamptogenys continua & Frequency of occurrence & Primary forest & Silva et al. [75] \\
\hline Gnamptogenys horni & Frequency of occurrence & Area at late succession stage & Vasconcelos [76] \\
\hline Gnamptogenys mediatrix & Frequency of occurrence & Forest fragment & Dias et al. [45] \\
\hline \multirow[t]{2}{*}{ Gnamptogenys moelleri } & Frequency of occurrence & Pasture & Dias et al. $[45]$ \\
\hline & Frequency of occurrence & Secondary forest and area at early succession & Schmidt and Diehl [52] \\
\hline Gnamptogenys reichenspergeri & Frequency of occurrence & Primary forest & Silva et al. [75] \\
\hline \multirow[t]{2}{*}{ Gnamptogenys striatula } & Presence/absence & Eucalyptus forestry & Marinho et al. [50] \\
\hline & IndVal & Forest—ground stratum & $\begin{array}{c}\text { Vasconcelos and } \\
\text { Vilhena [82] }\end{array}$ \\
\hline Gnamptogenys sulcata & Presence/absence & Area at early succession-wet season & Neves et al. [73] \\
\hline Gnamptogenys tortuolosa & Frequency of occurrence & Intermediate disturbed area & Vasconcelos [76] \\
\hline Heteroponera flava & Frequency of occurrence & Forest fragment & Dias et al. [45] \\
\hline Heteroponera microps & Frequency of occurrence & Disturbed habitat (Eucalyptus) & Ilha et al. [48] \\
\hline Hylomyrma balzani & Frequency of occurrence & Forest fragments & Lapola and Fowler [49] \\
\hline Hylomyrma reitteri & Frequency of occurrence & Forest fragments & Lapola and Fowler [49] \\
\hline Hypoponera foeda & Frequency of occurrence & Native forest remnant & Ilha et al. [48] \\
\hline Hypoponera foreli & Frequency of occurrence & Preserved savanna & Ramos et al. [37] \\
\hline Hypoponera opacior & Frequency of occurrence & Disturbed habitat (Eucalyptus) & Ilha et al. [48] \\
\hline \multirow[t]{2}{*}{ Labidus coecus } & Frequency of occurrence & Forest fragments & Lapola and Fowler [49] \\
\hline & Presence/absence & Undisturbed sites & Delabie et al. [35] \\
\hline \multirow[t]{3}{*}{ Labidus praedator } & Frequency of occurrence & Disturbed savanna & Ramos et al. [37] \\
\hline & Presence/absence & Eucalyptus forestry & Marinho et al. [50] \\
\hline & Frequency of occurrence & Secondary forest & Schmidt and Diehl [52] \\
\hline Leptogenys pusilla & Frequency of occurrence & Control site (nonburnt) & Teixeira et al. [39] \\
\hline Leptothorax asper & Presence/absence & Eucalyptus forestry & Marinho et al. [50] \\
\hline Leptothorax spininodis & Presence/absence & Eucalyptus forestry & Marinho et al. [50] \\
\hline \multirow[t]{4}{*}{ Linepithema humile } & Frequency of occurrence & Burnt site & Teixeira et al. [39] \\
\hline & Frequency of occurrence & Disturbed savanna & Ramos et al. [37] \\
\hline & Presence/absence & Eucalyptus forestry & Marinho et al. [50] \\
\hline & Frequency of occurrence & Forest fragments & Lapola and Fowler [49] \\
\hline Megalomyrmex goeldii & Frequency of occurrence & Area at early succession & Silva et al. [75] \\
\hline Mycetagroicus cerradensis & Frequency of occurrence & Disturbed savanna & Ramos et al. [37] \\
\hline Mycetarotes paralelus & Presence/absence & Area revegetated with native species & Pereira et al. [64] \\
\hline Mycetophylax conformis & Presence/absence & Strong human land-used-impacted sites & Delabie et al. [35] \\
\hline Myrmicocrypta foreli & Frequency of occurrence & Preserved savanna & Ramos et al. [37] \\
\hline Neivamyrmex orthonotus & Presence/absence & Eucalyptus forestry & Marinho et al. [50] \\
\hline Nesomyrmex spininodis & Presence/absence & Strong human land-used-impacted sites & Delabie et al. [35] \\
\hline Octostruma balzani & Frequency of occurrence & Area at intermediate succession & Braga et al. [54] \\
\hline \multirow[t]{2}{*}{ Octostruma jheringhi } & Frequency of occurrence & Forest fragment & Dias et al. [45] \\
\hline & Frequency of occurrence & Preserved savanna & Ramos et al. [37] \\
\hline Odontomachus affinis & Frequency of occurrence & Secondary forest & Silva et al. [75] \\
\hline Odontomachus bauri & Presence/absence & Eucalyptus forestry & Marinho et al. [50] \\
\hline Odontomachus brunneus & Frequency of occurrence & Preserved savanna & Ramos et al. [37] \\
\hline Odontomachus caelatus & Frequency of occurrence & Area at late succession stage & Vasconcelos [76] \\
\hline \multirow[t]{4}{*}{ Odontomachus chelifer } & Frequency of occurrence & Pasture & Braga et al. [54] \\
\hline & Frequency of occurrence & Preserved savanna & Ramos et al. [37] \\
\hline & Frequency of occurrence & Secondary forest and area at early succession & Schmidt and Diehl [52] \\
\hline & Frequency of occurrence & Secondary forest and area at early succession & Silva et al. [75] \\
\hline
\end{tabular}


Table 2: Continued.

\begin{tabular}{|c|c|c|c|}
\hline Ant species & Parameter & Habitat & Reference \\
\hline \multirow[t]{4}{*}{ Odontomachus haematodus } & Frequency of occurrence & Area at intermediate succession & Braga et al. [54] \\
\hline & Presence/absence & Burned restinga & Endringer et al. [38] \\
\hline & Frequency of occurrence & Control site (nonburnt) & Teixeira et al. [39] \\
\hline & IndVal & Forest—ground stratum & $\begin{array}{c}\text { Vasconcelos and } \\
\text { Vilhena [82] }\end{array}$ \\
\hline \multirow[t]{2}{*}{ Odontomachus meinerti } & Frequency of occurrence & Disturbed savanna & Ramos et al. [37] \\
\hline & Presence/absence & Eucalyptus forestry & Marinho et al. [50] \\
\hline Oxyepoecus plaumanni & Frequency of occurrence & Primary forest & Silva et al. [75] \\
\hline Oxyepoecus rastratus & Frequency of occurrence & Primary forest & Silva et al. [75] \\
\hline Pachycondyla apicalis & Presence/absence & Eucalyptus forestry & Marinho et al. [50] \\
\hline \multirow[t]{2}{*}{ Pachycondyla arhuaca } & Frequency of occurrence & Area at late succession stage & Braga et al. [54] \\
\hline & Presence/absence & Primary restinga & Endringer et al. [38] \\
\hline Pachycondyla bucki & Frequency of occurrence & Primary forest & Silva et al. [75] \\
\hline Pachycondyla crassinoda & IndVal & Forest—ground stratum & $\begin{array}{l}\text { Vasconcelos and } \\
\text { Vilhena [82] }\end{array}$ \\
\hline Pachycondyla ferruginea & Frequency of occurrence & Secondary forest and area at early succession & Silva et al. [75] \\
\hline Pachycondyla gilberti & Presence/absence & Eucalyptus forestry & Marinho et al. [50] \\
\hline \multirow[t]{3}{*}{ Pachycondyla harpax } & Presence/absence & Eucalyptus forestry & Marinho et al. [50] \\
\hline & IndVal & Forest—ground stratum & $\begin{array}{c}\text { Vasconcelos and } \\
\text { Vilhena [82] }\end{array}$ \\
\hline & Presence/absence & Low human land-use-impacted sites & Delabie et al. [35] \\
\hline Pachycondyla obscuricornis & Frequency of occurrence & Eucalyptus (reforestation) & Lapola and Fowler [49] \\
\hline \multirow[t]{2}{*}{ Pachycondyla stigma } & Frequency of occurrence & Control site (nonburnt) & Teixeira et al. [39] \\
\hline & Frequency of occurrence & Primary forest & Braga et al. [54] \\
\hline \multirow[t]{4}{*}{ Pachycondyla striata } & Frequency of occurrence & Preserved savanna & Ramos et al. [37] \\
\hline & Presence/absence & Savanna—cerrado sensu stricto & Marinho et al. [50] \\
\hline & Frequency of occurrence & Secondary forest and area at early succession & Schmidt and Diehl [52] \\
\hline & Frequency of occurrence & Secondary forest and area at early succession & Silva et al. [75] \\
\hline \multirow[t]{2}{*}{ Pachycondyla villosa } & Presence/absence & Burned restinga & Endringer et al. [38] \\
\hline & Frequency of occurrence & Disturbed savanna & Ramos et al. [37] \\
\hline \multirow[t]{2}{*}{ Paratrechina longicornis } & Presence/absence & Eucalyptus forestry & Marinho et al. [50] \\
\hline & Presence/absence & Undisturbed sites & Delabie et al. [35] \\
\hline Pheidole diligens & Presence/absence & Area at intermediate succession & Coelho et al. [60] \\
\hline Pheidole embolopyx & Frequency of occurrence & Area at late succession stage & Vasconcelos [76] \\
\hline Pheidole exigua & IndVal & Forest—ground stratum & $\begin{array}{c}\text { Vasconcelos and } \\
\text { Vilhena [82] }\end{array}$ \\
\hline \multirow[t]{2}{*}{ Pheidole fimbriata } & Frequency of occurrence & Preserved savanna & Ramos et al. [37] \\
\hline & Presence/absence & Savanna—cerrado sensu stricto & Marinho et al. [50] \\
\hline Pheidole fracticeps & IndVal & Forest—ground stratum & $\begin{array}{l}\text { Vasconcelos and } \\
\text { Vilhena [82] }\end{array}$ \\
\hline Pheidole radoszkowskii & Presence/absence & Low human land-use-impacted sites & Delabie et al. [35] \\
\hline Pheidole scalaris & Presence/absence & Area at early succession—wet season & Neves et al. [73] \\
\hline Pogonomyrmex abdominalis & Presence/absence & Eucalyptus forestry & Marinho et al. [50] \\
\hline Pogonomyrmex naegelii & Presence/absence & Area at intermediate succession & Coelho et al. [60] \\
\hline Prionopelta punctulata & Frequency of occurrence & Secondary forest and area at early succession & Silva et al. [75] \\
\hline Pseudomyrmex elongatus & Frequency of occurrence & Control site (nonburnt) & Teixeira et al. [39] \\
\hline Pseudomyrmex filiformis & Frequency of occurrence & Control site (nonburnt) & Teixeira et al. [39] \\
\hline Pseudomyrmex flavidulus & IndVal & Savanna-vegetation stratum & $\begin{array}{l}\text { Vasconcelos and } \\
\text { Vilhena [82] }\end{array}$ \\
\hline
\end{tabular}


Table 2: Continued.

\begin{tabular}{|c|c|c|c|}
\hline Ant species & Parameter & Habitat & Reference \\
\hline \multirow[t]{3}{*}{ Pseudomyrmex gracilis } & Presence/absence & Area at intermediate succession & Coelho et al. [60] \\
\hline & IndVal & Savanna_-vegetation stratum & $\begin{array}{c}\text { Vasconcelos and } \\
\text { Vilhena [82] }\end{array}$ \\
\hline & Presence/absence & Eucalyptus forestry & Marinho et al. [50] \\
\hline Pseudomyrmex kuenckeli & Presence/absence & Undisturbed sites & Delabie et al. [35] \\
\hline \multirow[t]{4}{*}{ Pseudomyrmex oculatus } & Presence/absence & Area at intermediate succession & Coelho et al. [60] \\
\hline & Frequency of occurrence & Control site (nonburnt) & Teixeira et al. [39] \\
\hline & Presence/absence & Eucalyptus forestry & Marinho et al. [50] \\
\hline & IndVal & Forest—vegetation stratum & $\begin{array}{c}\text { Vasconcelos and } \\
\text { Vilhena [82] }\end{array}$ \\
\hline Pseudomyrmex schuppi & Presence/absence & Area at intermediate succession & Coelho et al. [60] \\
\hline Pseudomyrmex sericeus & Presence/absence & Undisturbed sites & Delabie et al. [35] \\
\hline Pseudomyrmex simplex & Presence/absence & Eucalyptus forestry & Marinho et al. [50] \\
\hline Pseudomyrmex spiculus & Presence/absence & Undisturbed sites & Delabie et al. [35] \\
\hline \multirow[t]{5}{*}{ Pseudomyrmex tenuis } & Frequency of occurrence & Area at early succession & Vasconcelos [76] \\
\hline & IndVal & Forest—vegetation and ground stratum & $\begin{array}{c}\text { Vasconcelos and } \\
\text { Vilhena [82] }\end{array}$ \\
\hline & Presence/absence & Strong human land-use-impacted sites & Delabie et al. [35] \\
\hline & Frequency of occurrence & Area at intermediate succession & Braga et al. [54] \\
\hline & Frequency of occurrence & Control site (nonburnt) & Teixeira et al. [39] \\
\hline \multirow[t]{4}{*}{ Pseudomyrmex termitarius } & Presence/absence & Area at early succession—dry season & Neves et al. [73] \\
\hline & Frequency of occurrence & Pasture & Braga et al. [54] \\
\hline & IndVal & Savanna_-vegetation stratum & $\begin{array}{c}\text { Vasconcelos and } \\
\text { Vilhena [82] }\end{array}$ \\
\hline & Presence/absence & Eucalyptus forestry & Marinho et al. [50] \\
\hline Pyramica appretiata & Frequency of occurrence & Primary forest & Silva et al. [75] \\
\hline Pyramica denticulata & Frequency of occurrence & Area at early succession & Silva et al. [75] \\
\hline Pyramica lygatrix & Frequency of occurrence & Primary forest & Silva et al. [75] \\
\hline Pyramica rugithorax & Frequency of occurrence & Primary forest & Silva et al. [75] \\
\hline Pyramica schulzi & Presence/absence & Strong human land-use-impacted sites & Delabie et al. [35] \\
\hline \multirow[t]{2}{*}{ Pyramica subdentata } & Frequency of occurrence & Preserved savanna & Ramos et al. [37] \\
\hline & Frequency of occurrence & Secondary forest and area at early succession & Silva et al. [75] \\
\hline Pyramica zeteki & Frequency of occurrence & Preserved savanna & Ramos et al. [37] \\
\hline \multirow[t]{2}{*}{ Sericomymex bondari } & Frequency of occurrence & Control site (nonburnt) & Teixeira et al. [39] \\
\hline & Presence/absence & Low human land-use-impacted sites & Delabie et al. [35] \\
\hline Simopelta curvata & Frequency of occurrence & Pasture (edge) & Dias et al. [45] \\
\hline \multirow[t]{2}{*}{ Solenopsis geminata } & Frequency of occurrence & Area at early succession & Vasconcelos [76] \\
\hline & Frequency of occurrence & Caesalpinia echinata forest & $\begin{array}{c}\text { Santana-Reis and } \\
\text { Santos [51] }\end{array}$ \\
\hline \multirow[t]{2}{*}{ Solenopsis saevissima } & Frequency of occurrence & Disturbed sites & Ilha et al. [48] \\
\hline & Presence/absence & Eucalyptus forestry & Marinho et al. [50] \\
\hline \multirow[t]{3}{*}{ Solenopsis substituta } & Frequency of occurrence & Burnt site & Teixeira et al. [39] \\
\hline & Presence/absence & Eucalyptus forestry & Marinho et al. [50] \\
\hline & IndVal & Savanna—ground stratum & $\begin{array}{c}\text { Vasconcelos and } \\
\text { Vilhena [82] }\end{array}$ \\
\hline Sphinctomyrmex stali & Frequency of occurrence & Primary forest & Silva et al. [75] \\
\hline Stegomyrmex vizzotoi & Frequency of occurrence & Primary forest & Silva et al. [75] \\
\hline Strumigenys denticulata & Frequency of occurrence & Intermediate disturbed area & Vasconcelos [76] \\
\hline \multirow[t]{2}{*}{ Strumigenys elongata } & Frequency of occurrence & Area at early succession & Silva et al. [75] \\
\hline & Frequency of occurrence & Preserved savanna & Ramos et al. [37] \\
\hline
\end{tabular}


TABLE 2: Continued.

\begin{tabular}{llcc}
\hline Ant species & Parameter & Habitat & Reference \\
\hline Strumigenys perparva & Presence/absence & Savanna-cerrado sensu stricto & Marinho et al. [50] \\
& Frequency of occurrence & Preserved savanna & Ilha et al. [37] [48] \\
\hline Tapinoma melanocephalum & Frequency of occurrence & Disturbed habitat (Eucalyptus) & Lapola and Fowler [49] \\
& Frequency of occurrence & Forest fragments & Teixeira et al. [39] \\
& Frequency of occurrence & Control site (nonburnt) & Dias et al. [45] \\
\hline Trachymyrmex cornetzi & Frequency of occurrence & Pasture (edge) & Silva et al. [75] \\
\hline Trachymyrmex fuscus & Frequency of occurrence & Primary forest & Lapola and Fowler [49] \\
\hline Trachymyrmex zeteki & Frequency of occurrence & Forest fragments & Silva et al. [75] \\
\hline Typhlomyrmex major & Frequency of occurrence & Primary forest & Silva et al. [75] \\
\hline Typhlomyrmex pusillus & Frequency of occurrence & Primary forest & Coelho et al. [60] \\
\hline Wasmannia auropunctata & Presence/absence & Area at intermediate succession & Teixeira et al. [39] \\
\hline Wasmannia rochai & Frequency of occurrence & Control site (nonburnt) & Coelho et al. [60] \\
\hline
\end{tabular}

The majority of studies end at the seventh step of the "Procedural steps in bioindicator studies" according to McGeoch [7], which is "Based on the nature of the relationship, either accept or reject the species, higher level taxon or assemblage as an indicator," and just investigate the nature of the relationship between the disturbance and the indicator. To validate the organism as a suitable indicator, we must move to step eight (Establish the robustness of the indicator by developing and testing appropriate hypotheses under different conditions) — establish the robustness of the indicator by testing the same relationship in other areas or at different times (to validate the indicator) $[6,14,103]$.

We would like to flag some issues to improve and validate the use of ants as indicators in environmental monitoring programs, including consideration of robust criteria for the validation of ants as indicators, sampling in different seasons and under different disturbances with comparable methodologies, collecting ants with different sampling methodologies in order to recognize that the responses of different ant life styles could be different for the same disturbance, and evaluation of different environmental parameters (biotic and abiotic) to correlate with the ants' response along the disturbance/restoration gradients. The search for indicator ant species should be with analyses that consider their fidelity and specificity to the habitats (e.g., "IndVal" index), in order to more quickly achieve monitoring goals. Finally, evaluating the functional loss of ant species in disturbed habitats will improve predictions about the functional implication of the disturbance.

Moreover, incorporating new approaches that efficiently simplify the study may help to decrease the problems related to time spent identifying ant species, as suggested by Groc et al. [85]. In this study, the authors introduced a new method based on mixed-level taxonomic sufficiency, highly focused on higher-taxon surrogacy. Under this method, only ant species pre established as "indicator taxa" must be taxonomically identified to species level, while other species may be identified to higher (and easier to identify) levels, such as genera. By using this mixed-level approach, the authors argue that a considerable improvement in cost effectiveness can be achieved, mainly by reducing the necessity for welltrained taxonomists to be involved in the study. This is highly desirable in monitoring programs, where time and budget are key limiting factors.

Also, species which have been identified as possible indicators because they occur in specific habitats or conditions still require validation for reliable use as bioindicators, and their presence or frequency in specific conditions can generate testable hypothesis about their relationship with these habitats and conditions, which in turn can validate the use of these species as bioindicators.

In conclusion, we point out that the use of ants as indicators in Brazil has been improving each year. Ants are a useful tool not only because they are sensitive to environmental changes, as related in the papers we reviewed but also because they are keystone species in several ecological processes and, therefore, provide reliable inferences about the ecological and functional implications of disturbances.

We should continue to study ants in Brazil, with proper a priori hypothesis tests and sampling designs, statistical analysis and standardized methods, in order to reach the same widespread acceptance of ants as indicators that is common in Australia, as well as to improve our understanding of ant dynamics for predictive frameworks. Moreover, we need to build an effective bridge between our accumulated knowledge (almost 25 years of research) of ants as bioindicators and monitoring programs developed to examine natural resources and areas.

\section{Acknowledgments}

This study resulted from the research project: CRA 270/07 "Utilização de formigas como bioindicadoras de impacto ambiental e de sua recuperação em Cerrado e em Mata Atlântica." The authors are grateful to Jacques H. C. Delabie for encouraging the elaboration of this paper, to Jonathan D. Majer for his kind attention in providing several papers and to 
Patty Ramirez for her valuable suggestions in the English expression. The authors received grants and funding from the FAPEMIG, CAPES, and CNPq.

\section{References}

[1] E. O. Wilson, "On the future of conservation biology: editorial," Conservation Biology, vol. 14, no. 1, pp. 1-3, 2000.

[2] K. S. Bawa, W. J. Kress, N. M. Nadkarni et al., "Tropical ecosystems into the 21st century," Science, vol. 306, no. 5694, pp. 227-228, 2004.

[3] J. K. A. Benhin, "Agriculture and deforestation in the tropics: a critical theoretical and empirical review," Ambio, vol. 35, no. 1, pp. 9-16, 2006.

[4] G. J. Niemi and M. E. McDonald, "Application of ecological indicators," Annual Review of Ecology, Evolution, and Systematics, vol. 35, pp. 89-111, 2004.

[5] P. J. Goodsell, A. J. Underwood, and M. G. Chapman, "Evidence necessary for taxa to be reliable indicators of environmental conditions or impacts," Marine Pollution Bulletin, vol. 58, no. 3, pp. 323-331, 2009.

[6] T. A. Gardner, Monitoring Forest Biodiversity: Improving Conservation through Ecologically-Responsible Management, Earthscan, London, UK, 2010.

[7] M. A. McGeoch, "The selection, testing and application of terrestrial insects as bioindicators," Biological Reviews of the Cambridge Philosophical Society, vol. 73, no. 2, pp. 181-201, 1998.

[8] M. Dufrêne and P. Legendre, "Species assemblages and indicator species: the need for a flexible asymmetrical approach," Ecological Monographs, vol. 67, no. 3, pp. 345-366, 1997.

[9] J. Hilty and A. Merenlender, "Faunal indicator taxa selection for monitoring ecosystem health," Biological Conservation, vol. 92, no. 2, pp. 185-197, 2000.

[10] P. J. Folgarait, "Ant biodiversity and its relationship to ecosystem functioning: a review," Biodiversity and Conservation, vol. 7, no. 9, pp. 1221-1244, 1998.

[11] L. Lach, C. L. Parr, and K. L. Abbott, Ant Ecology, Oxford University Press, Oxford, UK, 2010.

[12] D. Agosti, J. D. Majer, L. E. Alonso, and R. Schultz, Ants: Standard Methods for Measuring and Monitoring Biodiversity, Smithsonian Institution Press, Washington, DC, USA, 2000.

[13] E. C. Underwood and B. L. Fisher, "The role of ants in conservation monitoring: if, when, and how," Biological Conservation, vol. 132, no. 2, pp. 166-182, 2006.

[14] S. M. Philpott, I. Perfecto, I. Armbrecht, and C. L. Parr, "Ant diversity and function in disturbed and changing habitats," in Ant Ecology, L. Lach, C. L. Parr, and K. L. Abbott, Eds., pp. 137-156, Oxford University Press, Oxford, UK, 2010.

[15] J. D. Majer, "Ants: bio-indicators of minesite rehabilitation, land-use, and land conservation," Environmental Management, vol. 7, no. 4, pp. 375-383, 1983.

[16] B. D. Hoffmann and A. N. Andersen, "Responses of ants to disturbance in Australia, with particular reference to functional groups," Austral Ecology, vol. 28, no. 4, pp. 444-464, 2003.

[17] A. N. Andersen and J. D. Majer, "Ants show the way Down Under: invertebrate as bioindicators in land management," Frontiers in Ecology and the Environment, vol. 2, pp. 291-298, 2004.

[18] A. N. Andersen, A. Fisher, B. D. Hoffmann, J. L. Read, and R. Richards, "Use of terrestrial invertebrates for biodiversity monitoring in Australian rangelands, with particular reference to ants," Austral Ecology, vol. 29, no. 1, pp. 87-92, 2004.

[19] J. D. Majer, K. E. C. Brennan, and M. L. Moir, "Invertebrates and the restoration of a forest ecosystem: 30 years of research following bauxite mining in Western Australia," Restoration Ecology, vol. 15, no. 4, pp. S104-S115, 2007.

[20] C. Gómez, D. Casellas, J. Oliveras, and J. M. Bas, "Structure of ground-foraging ant assemblages in relation to land-use change in the northwestern Mediterranean region," Biodiversity and Conservation, vol. 12, no. 10, pp. 2135-2146, 2003.

[21] H. van Hamburg, A. N. Andersen, W. J. Meyer, and H. G. Robertson, "Ant community development on rehabilitated ash dams in the South African highveld," Restoration Ecology, vol. 12, no. 4, pp. 552-558, 2004.

[22] L. Ottonetti, L. Tucci, and G. Santini, "Recolonization patterns of ants in a rehabilitated lignite mine in Central Italy: potential for the use of Mediterranean ants as indicators of restoration processes," Restoration Ecology, vol. 14, no. 1, pp. 60-66, 2006.

[23] K. C. Fagan, R. F. Pywell, J. M. Bullock, and R. H. Marrs, "Are ants useful indicators of restoration success in temperate grasslands?" Restoration Ecology, vol. 18, no. 3, pp. 373-379, 2010.

[24] C. Castracani, D. A. Grasso, A. Fanfani, and A. Mori, "The ant fauna of Castelporziano Presidential Reserve (Rome, Italy) as a model for the analysis of ant community structure in relation to environmental variation in Mediterranean ecosystems," Journal of Insect Conservation, vol. 14, no. 6, pp. 585-594, 2010.

[25] J. R. Verdú, C. Numa, and O. Hernández-Cuba, "The influence of landscape structure on ants and dung beetles diversity in a Mediterranean savanna-Forest ecosystem," Ecological Indicators, vol. 11, no. 3, pp. 831-839, 2011.

[26] R. R. Silva and C. R. F. Brandão, "Formigas (Hymenoptera: Formicidae) como indicadores da qualidade ambiental e da biodiversidade de outros invertebrados terrestres," Biotemas, vol. 12, pp. 55-73, 1999.

[27] J. M. Queiroz, F. S. Almeida, and M. P. S. Pereira, "Conservação da biodiversidade e o papel das formigas (Hymenoptera: Formicidae) em agroecossistemas," Floresta e Ambiente, vol. 13, pp. 37-45, 2006.

[28] D. Baretta, Á. L. Mafra, J. C. P. Santos, C. V. T. Do Amarante, and I. Bertol, "Multivariate analysis of soil fauna under different soil tillage and crop management systems," Pesquisa Agropecuaria Brasileira, vol. 41, no. 11, pp. 1675-1679, 2006.

[29] A. O. Merlim, J. G. M. Guerra, R. M. Junqueira, and A. M. Aquino, "Soil macrofauna in cover crops of figs grown under organic management," Scientia Agricola, vol. 62, pp. 57-61, 2005.

[30] L. R. S. Lacau, R. Zanetti, J. H. C. Delabie et al., "Respostas das guildas de formigas (Hymenoptera: Formicidae) a práticas silviculturais em plantio de eucaliptos," Agrotropica, vol. 20, pp. 61-72, 2008 .

[31] L. A. P. L. Nunes, J. A. Araújo Filho, and R. I. Q. Meneses, "Recolonização da fauna edáfica em áreas de caatinga submetidas a queimadas," Caatinga, vol. 21, pp. 214-220, 2008.

[32] L. S. Ramos, C. G. S. Marinho, R. Zanetti, J. H. C. Delabie, and M. N. Schlindwein, "Impact of formicid granulated baits on non-target ants in eucalyptus plantations according to two forms of application," Neotropical Entomology, vol. 32, no. 2, pp. 231-237, 2003.

[33] A. F. Silva, B. Meireles, J. Da Silva Rosa, M. W. De Oliveira, M. S. De Castro Morini, and A. F. De Oliveira, "Evaluation of the level of metals in Camponotus rufipes (Hymenoptera: 
Formicidae) collected in different environments," Sociobiology, vol. 47, no. 2, pp. 293-304, 2006.

[34] K. S. Carvalho, A. L. B. de Souza, M. S. Pereira, C. P. Sampaio, and J. H. C. Delabie, "Comunidade de formigas epígeas no Ecótono Mata de Cipó, domínio da Mata Atlântica, BA, Brasil," Acta Biológica Leopoldensia, vol. 26, pp. 249-257, 2004.

[35] J. H. C. Delabie, V. R. L. D. M. Paim, I. C. Do Nascimento, S. Campiolo, and C. D. S. F. Mariano, "Ants as biological indicators of human impact in mangroves of the southeastern coast of Bahia, Brazil," Neotropical Entomology, vol. 35, no. 5, pp. 602-615, 2006.

[36] N. L. Hites, M. A. N. Mourão, F. O. Araújo, M. V. C. Melo, J. C. De Biseau, and Y. Quinet, "Diversity of the grounddwelling ant fauna (Hymenoptera: Formicidae) of a moist, montane forest of the semi-arid Brazilian "Nordeste"' Revista de Biologia Tropical, vol. 53, no. 1-2, pp. 165-173, 2005.

[37] L. D. Ramos, R. Z. B. Filho, J. H. C. Delabie et al., "Ant communities (Hymenoptera: Formicidae) of the leaf-litter in cerrado "stricto sensu" areas in Minas Gerais, Brazil," Lundiana, vol. 4, no. 2, pp. 95-102, 2003.

[38] F. B. Endringer, I. A. Santos, M. Da Cunha Teixeira, and J. H. Schoereder, "Ant species richness in sand dune environments following burning (Hymenoptera: Formicidae)," Sociobiology, vol. 51, no. 2, pp. 415-423, 2008.

[39] M. C. Teixeira, J. H. Schoereder, J. T. Nascimento, and J. N. C. Louzada, "Response of ant communities to sand dune vegetation burning in Brazil (Hymenoptera: Formicidae)," Sociobiology, vol. 45, no. 3, pp. 631-641, 2005.

[40] K. S. Carvalho and H. L. Vasconcelos, "Forest fragmentation in central Amazonia and its effects on litter-dwelling ants," Biological Conservation, vol. 91, no. 2-3, pp. 151-157, 1999.

[41] J. P. Gomes, L. Iannuzzi, and I. R. Leal, "Resposta da comunidade de formigas aos atributos dos fragmentos e da vegetação em uma paisagem da floresta Atlântica nordestina," Neotropical Entomology, vol. 39, no. 6, pp. 898-905, 2010.

[42] M. S. Santos, J. N. C. Louzada, N. Dias, R. Zanetti, J. H. C. Delabie, and I. C. Nascimento, "Litter ants richness (Hymenoptera, Formicidae) in remnants of a semi-deciduous forest in the Atlantic rain forest, Alto do Rio Grande region, Minas Gerais, Brazil," Iheringia - Serie Zoologia, vol. 96, no. 1, pp. 95-101, 2006.

[43] R. C. Fonseca and E. Diehl, "Riqueza de formigas (Hymenoptera, Formicidae) epigéicas em povoamentos de Eucaliptus spp. (Myrtaceae) de diferentes idades no Rio Grande do Sul," Revista Brasileira de Entomologia, vol. 48, pp. 95-100, 2004.

[44] A. G. Castro and M. V. B. Queiroz, "Estrutura e organização de uma comunidade de formigas em agro-ecossistemas neotropical," Anais da Sociedade Entomológica do Brasil, vol. 16, pp. 363-375, 1987.

[45] N. S. Dias, R. Zanetti, M. S. Santos, J. Louzada, and J. Delabie, "Interaction between forest fragments and adjacent coffee and pasture agroecosystems: responses of the ant communities (Hymenoptera, Formicidae)," Iheringia - Serie Zoologia, vol. 98, no. 1, pp. 136-142, 2008.

[46] E. Diehl, D. F. Florencio, F. A. Schmidt, and L. V. A. Menzel, "Riqueza e composição das comunidades de formigas e de térmitas na floresta nacional de São Francisco de Paula (FLONA-SFP), RS," Acta Biologica Leopondensia, vol. 27, pp. 99-106, 2005.

[47] J. B. V. Gomes, A. C. Barreto, M. M. Michereff Filho et al., "Relationship among soil attributes and ant activity in restinga soils," Revista Brasileira de Ciencia do Solo, vol. 34, no. 1, pp. $67-78,2010$.
[48] C. Ilha, J. A. Lutinski, D. V. M. Pereira, and F. R. M. Garcia, "Riqueza de formigas (Hymenoptera: Formicidae) da Bacia da Sanga Caramuru, município de Chapecó-SC," Biotemas, vol. 22, pp. 95-105, 2009.

[49] D. M. Lapola and H. G. Fowler, "Questioning the implementation of habitat corridors: a case study in interior São Paulo using ants as bioindicators," Brazilian Journal of Biology, vol. 68, no. 1, pp. 11-20, 2008.

[50] C. G. S. Marinho, R. Zanetti, J. H. C. Delabie, M. N. Schlindwein, and L. D. S. Ramos, "Ant (hymenoptera: formicidae) diversity in eucalyptus (myrtaceae) plantations and cerrado litter in Minas Gerais, Brazil," Neotropical Entomology, vol. 31, no. 2, pp. 187-195, 2002.

[51] V. P. G. Santana-Reis and G. M. M. Santos, "Influência da estrutura do habitat em comunidades de formigas (Hymenoptera - Formicidae) em Feira de Santana, Bahia, Brasil," Sientibus, vol. 1, pp. 66-70, 2001.

[52] F. A. Schmidt and E. Diehl, "What is the effect of soil use on ant communities?" Neotropical Entomology, vol. 37, no. 4, pp. 381-388, 2008.

[53] A. A. Tavares, P. C. Bispo, and A. C. Zanzini, "Effect of collect time on communities of epigaeic ants (Hymenoptera: Formicidae) in areas of Eucalyptus cloeziana and cerrado," Neotropical Entomology, vol. 37, no. 2, pp. 126-130, 2008.

[54] D. L. Braga, J. N. C. Louzada, R. Zanetti, and J. Delabie, "Rapid evaluation of ant diversity in land use systems in Southern Bahia, Brazil," Neotropical Entomology, vol. 39, no. 4, pp. 464-469, 2010.

[55] J. D. Majer and J. H. C. Delabie, "Comparison of the ant communities of annually inundated and terra firme forests at Trombetas in the Brazilian Amazon," Insectes Sociaux, vol. 41, no. 4, pp. 343-359, 1994.

[56] K. A. B. Kalif, C. Azevedo-Ramos, P. Moutinho, and S. A. O. Malcher, "The effect of logging on the ground-foraging ant community in eastern Amazonia," Studies on Neotropical Fauna and Environment, vol. 36, no. 3, pp. 215-219, 2001.

[57] Y. J. Barros, V. de Freitas Melo, K. D. Sautter et al., "Soil quality indicators in lead mining and metalurgy area. II - mesofauna and plants," Revista Brasileira de Ciencia do Solo, vol. 34, no. 4, pp. 1413-1426, 2010.

[58] E. Diehl, C. E. Sanhudo, and E. Diehl-Fleig, "Ground-dwelling ant fauna of sites with high levels of copper," Brazilian Journal of Biology, vol. 64, no. 1, pp. 33-39, 2004.

[59] M. P. Pais and E. M. Varanda, "Arthropod recolonization in the restoration of a semideciduous forest in southeastern Brazil," Neotropical Entomology, vol. 39, no. 2, pp. 198-206, 2010.

[60] M. S. Coelho, G. W. Fernandes, J. C. Santos, and J. H. C. Delabie, "Ants (Hymenoptera: Formicidae) as bioindicators of land restoration in a brazilian atlantic forest fragment," Sociobiology, vol. 54, no. 1, pp. 51-63, 2009.

[61] C. B. Costa, S. P. Ribeiro, and P. T. A. Castro, "Ants as bioindicators of natural succession in savanna and riparian vegetation impacted by dredging in the Jequitinhonha River Basin, Brazil," Restoration Ecology, vol. 18, no. 1, pp. 148-157, 2010.

[62] J. D. Majer, "Ant recolonisation of rehabilitated bauxite mines of Pocos de Caldas, Brazil," Journal of Tropical Ecology, vol. 8, no. 1, pp. 97-108, 1992.

[63] J. D. Majer, "Ant recolonization of rehabilitated bauxite mines at Trombetas, Pará, Brazil," Journal of Tropical Ecology, vol. 12, no. 2, pp. 257-273, 1996.

[64] M. P. D. S. Pereira, J. M. Queiroz, R. Valcarcel, and A. J. Mayhé-Nunes, "Ant fauna as a tool for the monitoring of 
a rehabilited sand mine at Ilha da Madeira, Itaguaí, RJ," Ciencia Florestal, vol. 17, no. 3, pp. 197-204, 2007.

[65] H. L. Vasconcelos, E. H. M. Vieira-Neto, F. M. Mundim, and E. M. Bruna, "Roads alter the colonization dynamics of a keystone herbivore in neotropical savannas," Biotropica, vol. 38, no. 5, pp. 661-665, 2006.

[66] K. Schmidt, R. Corbetta, and A. J. A. Camargo, "Formigas (Hymenoptera: Formicidae) da Ilha João da Cunha, SC: composição e diversidade," Biotemas, vol. 18, pp. 57-71, 2005.

[67] J. H. Bihn, M. Verhaagh, M. Brändle, and R. Brandl, "Do secondary forests act as refuges for old growth forest animals? Recovery of ant diversity in the Atlantic forest of Brazil," Biological Conservation, vol. 141, no. 3, pp. 733-743, 2008.

[68] J. H. Bihn, M. Verhaagh, and R. Brandl, "Ecological stoichiometry along a gradient of forest succession: bait preferences of litter ants," Biotropica, vol. 40, no. 5, pp. 597-599, 2008.

[69] J. H. Bihn, G. Gebauer, and R. Brandl, "Loss of functional diversity of ant assemblages in secondary tropical forests," Ecology, vol. 91, no. 3, pp. 782-792, 2010.

[70] A. G. Castro, M. V. B. Queiroz, and L. M. Araújo, "O papel do distúrbio na estrutura de comunidades de formigas (Hymenoptera, Formicidae)," Revista Brasileira de Entomologia, vol. 34, pp. 201-213, 1990.

[71] I. R. Leal, S. O. Ferreira, and A. V. L. Freitas, "Diversidade de formigas de solo em um gradiente sucessional de Mata Atlântica, ES, Brasil," Biotemas, vol. 6, pp. 42-53, 1993.

[72] F. S. Neves, R. F. Braga, and B. G. Madeira, "Diversidade de formigas arborícolas em três estágios sucessionais de uma floresta estacional decidual no norte de Minas Gerais," Unimontes Científica, vol. 8, pp. 59-68, 2006.

[73] F. S. Neves, R. F. Braga, M. M. Do EspíritoSanto, J. H. C. Delabie, G. W. Fernandes, and G. A. Sánchez-Azofeifa, "Diversity of arboreal ants in a brazilian tropical dry forest: effects of seasonality and successional stage," Sociobiology, vol. 56, no. 1, pp. 177-194, 2010.

[74] J. C. Santos, J. H. C. Delabie, and G. W. Fernandes, "A 15-year post evaluation of the fire effects on ant community in an area of Amazonian forest," Revista Brasileira de Entomologia, vol. 52, no. 1, pp. 82-87, 2008.

[75] R. R. Silva, R. S. Machado Feitosa, and F. Eberhardt, "Reduced ant diversity along a habitat regeneration gradient in the southern Brazilian Atlantic Forest," Forest Ecology and Management, vol. 240, no. 1-3, pp. 61-69, 2007.

[76] H. L. Vasconcelos, "Effects of forest disturbance on the structure of ground-foraging ant communities in central Amazonia," Biodiversity and Conservation, vol. 8, no. 3, pp. 409-420, 1999.

[77] H. L. Vasconcelos, J. M. S. Vilhena, and G. J. A. Caliri, "Responses of ants to selective logging of a central Amazonian forest," Journal of Applied Ecology, vol. 37, no. 3, pp. 508-514, 2000.

[78] M. J. Angilletta, R. S. Wilson, A. C. Niehaus, M. W. Sears, C. A. Navas, and P. L. Ribeiro, "Urban physiology: city ants possess high heat tolerance," PLoS One, vol. 2, no. 2, article no. e258, 2007.

[79] E. Diehl, F. Sacchett, and E. Z. Albuquerque, "Riqueza de formigas de solo na praia da Pedreira, Parque Estadual de Itapuã, Viamão, RS, Brasil," Revista Brasileira de Entomologia, vol. 49, pp. 552-556, 2005.

[80] I. R. Leal, A. G. D. Bieber, M. Tabarelli, and A. N. Andersen, "Biodiversity surrogacy: indicator taxa as predictors of total species richness in Brazilian Atlantic forest and Caatinga,"
Biodiversity and Conservation, vol. 19, no. 12, pp. 3347-3360, 2010.

[81] D. T. Lopes, J. Lopes, I. C. do Nascimento, and J. H. Delabie, "Epigeic ants diversity (Hymenoptera, Formicidae) in three environments in Mata dos Godoy State Park, Londrina, State of Paraná, Brazil," Iheringia - Serie Zoologia, vol. 100, no. 1, pp. 84-90, 2010.

[82] H. L. Vasconcelos and J. M. S. Vilhena, "Species turnover and vertical partitioning of ant assemblages in the Brazilian Amazon: a comparison of forests and savannas," Biotropica, vol. 38, no. 1, pp. 100-106, 2006.

[83] R. R. Silva and R. Silvestre, "Riqueza da fauna de formigas (Hymenoptera: Formicidae) que habita as camadas superficiais do solo em Seara, Santa Catarina," Papéis Avulsos de Zoologia, vol. 44, pp. 1-11, 2004.

[84] R. Silvestre and R. R. Silva, "Guildas de formigas da estação ecológica Jataí, Luiz Antônio - SP - sugestões para a aplicação do modelo de guildas como bio-indicadores ambientais," Biotemas, vol. 14, pp. 37-69, 2001.

[85] S. Groc, J. H. C. Delabie, J. T. Longino et al., "A new method based on taxonomic sufficiency to simplify studies on Neotropical ant assemblages," Biological Conservation, vol. 143, no. 11, pp. 2832-2839, 2010.

[86] C. A. Joly, R. R. Rodrigues, J. P. Metzger et al., "Biodiversity conservation research, training, and policy in são paulo," Science, vol. 328, no. 5984, pp. 1358-1359, 2010.

[87] A. Petherick, "High hopes for Brazilian science," Nature, vol. 465, no. 7299, pp. 674-675, 2010.

[88] K. T. R. Wilkie, A. L. Mertl, and J. F. A. Traniello, "Biodiversity below ground: probing the subterranean ant fauna of Amazonia," Naturwissenschaften, vol. 94, no. 9, pp. 725-731, 2007.

[89] J. H. Lawton, D. E. Bignell, B. Bolton et al., "Biodiversity inventories, indicator taxa and effects of habitat modification in tropical forest," Nature, vol. 391, no. 6662, pp. 72-76, 1998.

[90] C. R. Ribas, R. R. C. Solar, R. B. F. Campos, F. A. Schmidt, C. L. Valentim, and J. H. Schoereder, "Can ants be used as indicators of environmental impacts caused by arsenic?" Journal of Insect Conservation. In press.

[91] C. R. Ribas, F. A. Schmidt, R. R. C. Solar, R. B. F. Campos, C. L. Valentim, and J. H. Schoereder, "Ants as indicators of the success of rehabilitation efforts in deposits of gold mining tailings," Restoration Ecology. In press.

[92] B. T. Bestelmeyer, D. Agosti, L. E. Alonso et al., "Field techniques for the study of ground dwelling ants. An overview, description, and evaluation," in Ants: Standard Methods for Measuring and Monitoring Biodiversity, D. Agosti, J. D. Majer, L. E. Alonso, and T. R. Schultz, Eds., pp. 122-144, Smithsonian Institution Press, London, UK, 2000.

[93] J. R. Gollan, L. L. D. Bruyn, N. Reid, D. Smith, and L. Wilkie, "Can ants be used as ecological indicators of restoration progress in dynamic environments? A case study in a revegetated riparian zone," Ecological Indicators, vol. 11, no. 6, pp. 1517-1525, 2011.

[94] B. D. Hoffmann, "Using ants for rangeland monitoring: global patterns in the responses of ant communities to grazing," Ecological Indicators, vol. 10, no. 2, pp. 105-111, 2010.

[95] R. R. Dunn, "Recovery of faunal communities during tropical forest regeneration," Conservation Biology, vol. 18, no. 2, pp. 302-309, 2004.

[96] J. D. Majer, J. E. Day, E. D. Kabay, and W. S. Perriman, "Recolonization by ants in bauxite mines rehabilitated by a number of different methods," Journal of Applied Ecology, vol. 21, no. 1, pp. 255-257, 1984. 
[97] J. D. Majer and O. G. Nichols, "Long-term recolonization patterns of ants in Western Australian rehabilitated bauxite mines with reference to their use as indicators of restoration success," Journal of Applied Ecology, vol. 35, no. 1, pp. 161$182,1998$.

[98] O. G. Nichols and F. M. Nichols, "Long-term trends in faunal recolonization after bauxite mining in the Jarrah forest of Southwestern Australia," Restoration Ecology, vol. 11, no. 3, pp. 261-272, 2003.

[99] D. C. Cardoso, T. G. Sobrinho, and J. H. Schoereder, "Ant community composition and its relationship with phytophysiognomies in a Brazilian Restinga," Insectes Sociaux, vol. 57, no. 3, pp. 293-301, 2010.

[100] M. A. McGeoch, B. J. Van Rensburg, and A. Botes, "The verification and application of bioindicators: a case study of dung beetles in a savanna ecosystem," Journal of Applied Ecology, vol. 39, no. 4, pp. 661-672, 2002.

[101] A. Nakamura, C. P. Catterall, A. P. N. House, R. L. Kitching, and C. J. Burwell, "The use of ants and other soil and litter arthropods as bio-indicators of the impacts of rainforest clearing and subsequent land use," Journal of Insect Conservation, vol. 11, no. 2, pp. 177-186, 2007.

[102] G. R. Pohl, D. W. Langor, and J. R. Spence, "Rove beetles and ground beetles (Coleoptera: Staphylinidae, Carabidae) as indicators of harvest and regeneration practices in western Canadian foothills forests," Biological Conservation, vol. 137, no. 2, pp. 294-307, 2007.

[103] R. A. da Mata, M. McGeoch, and R. Tidon, "Drosophilid assemblages as a bioindicator system of human disturbance in the Brazilian Savanna," Biodiversity and Conservation, vol. 17, no. 12, pp. 2899-2916, 2008.

[104] T. A. Gardner, J. Barlow, I. S. Araujo et al., "The cost-effectiveness of biodiversity surveys in tropical forests," Ecology Letters, vol. 11, no. 2, pp. 139-150, 2008.

[105] G. F. Smith, T. Gittings, M. Wilson et al., "Identifying practical indicators of biodiversity for stand-level management of plantation forests," Biodiversity and Conservation, vol. 17, no. 5, pp. 991-1015, 2008.

[106] Y. Basset, J. F. Mavoungou, J. B. Mikissa et al., "Discriminatory power of different arthropod data sets for the biological monitoring of anthropogenic disturbance in tropical forests," Biodiversity and Conservation, vol. 13, no. 4, pp. 709-732, 2004.

[107] Y. Basset, O. Missa, A. Alonso et al., "Changes in arthropod assemblages along a wide gradient of disturbance in gabon," Conservation Biology, vol. 22, no. 6, pp. 1552-1563, 2008.

[108] S. M. Philpott, W. J. Arendt, I. Armbrecht et al., "Biodiversity loss in Latin American coffee landscapes: review of the evidence on ants, birds, and trees," Conservation Biology, vol. 22, no. 5, pp. 1093-1105, 2008.

[109] M. Kessler, S. Abrahamczyk, M. Bos et al., "Alpha and beta diversity of plants and animals along a tropical land-use gradient," Ecological Applications, vol. 19, no. 8, pp. 21422156, 2009. 

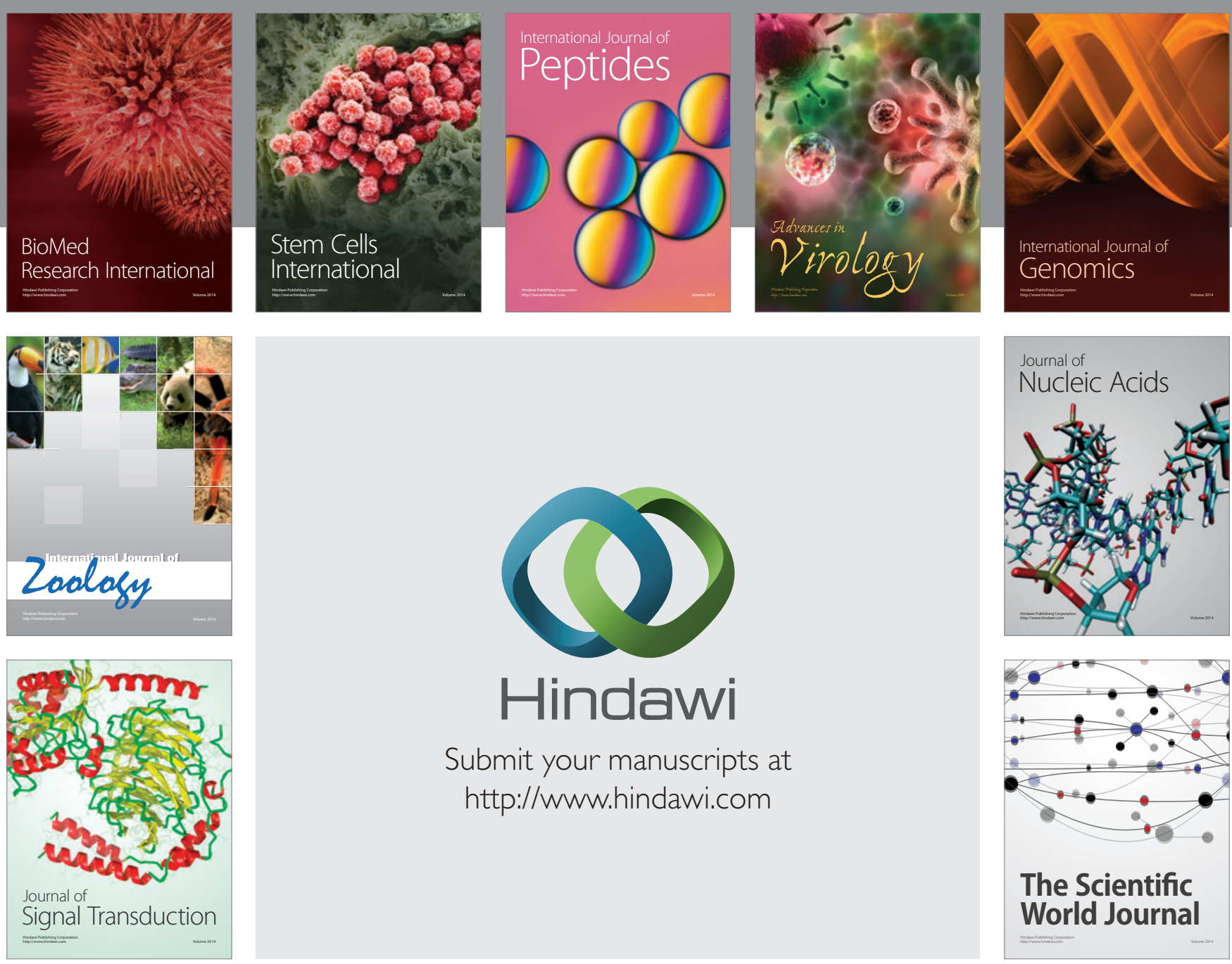

Submit your manuscripts at

http://www.hindawi.com
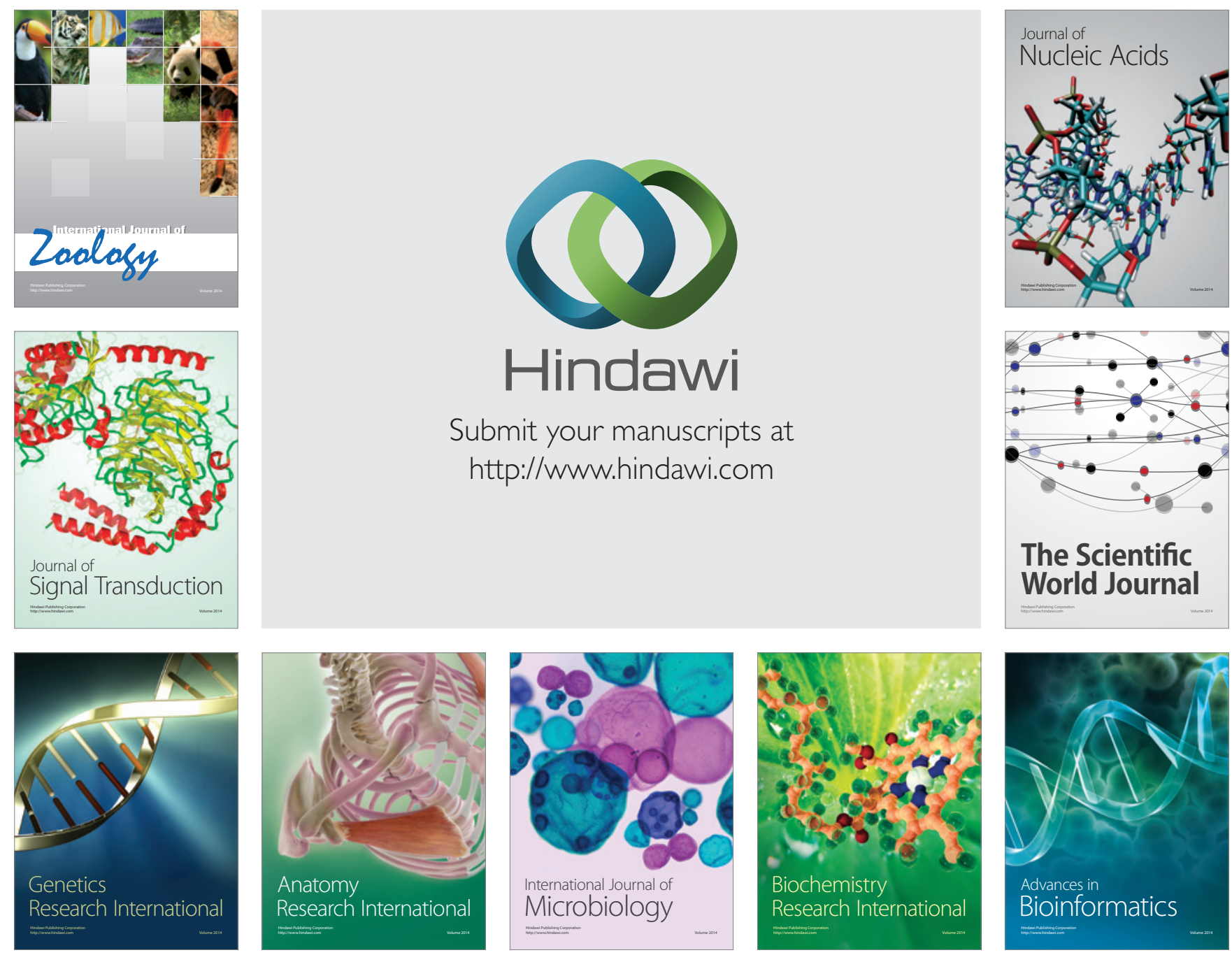

The Scientific World Journal
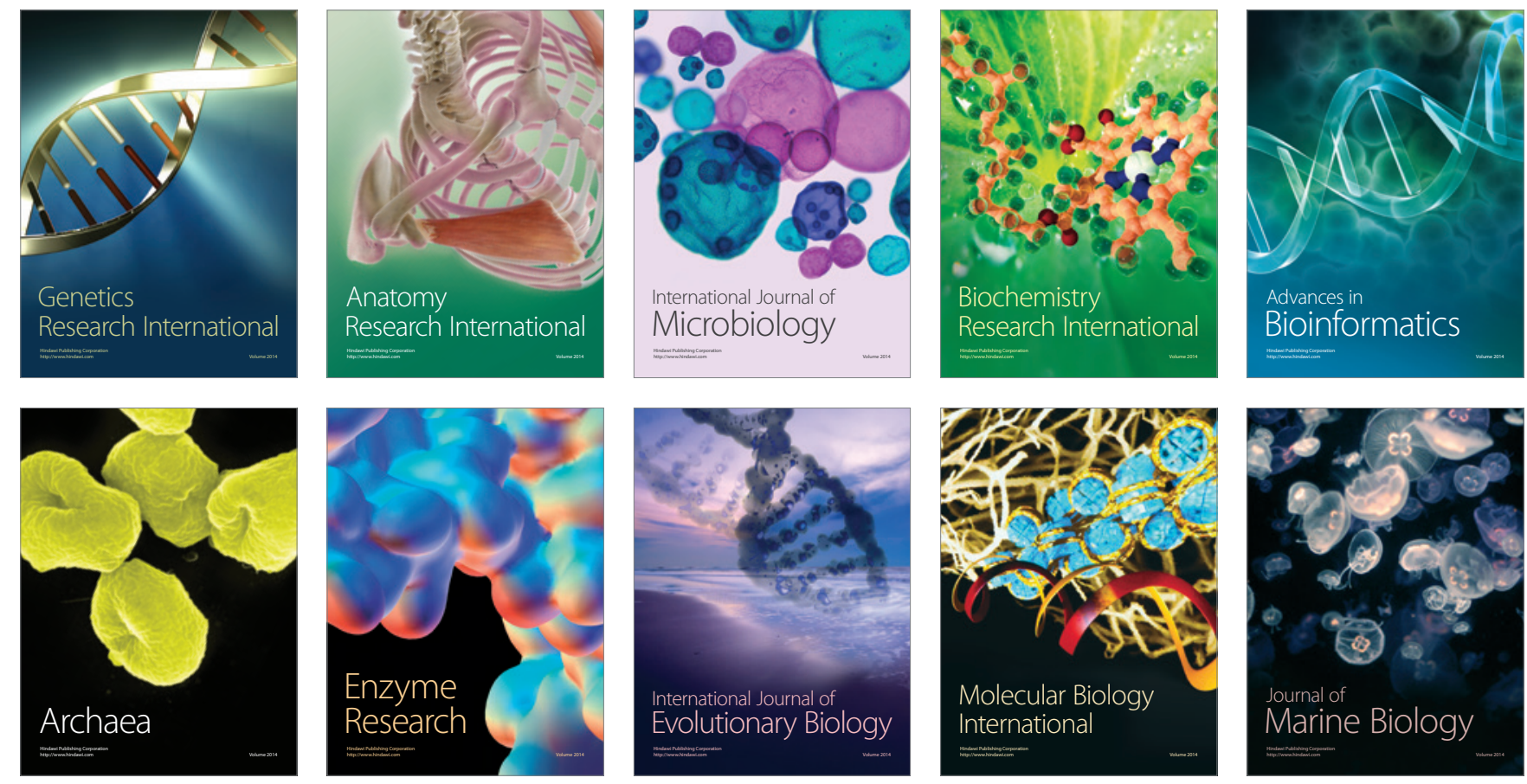